NBER WORKING PAPER SERIES

\title{
BELIEF DISAGREEMENT AND PORTFOLIO CHOICE
}

\author{
Maarten Meeuwis \\ Jonathan A. Parker \\ Antoinette Schoar \\ Duncan I. Simester \\ Working Paper 25108 \\ http://www.nber.org/papers/w25108 \\ NATIONAL BUREAU OF ECONOMIC RESEARCH \\ 1050 Massachusetts Avenue \\ Cambridge, MA 02138
}

September 2018, Revised June 2021

For helpful comments, we thank Roland Benabou, Ing-Haw Cheng, James Choi, Gregory Huber, Steve Nicholson, Lubos Pastor, Chester Spatt, Johannes Stroebel, David Thesmar, PaulWillen, and seminar participants at Boston College, the Federal Reserve Bank of Boston, Goethe University, Ohio State, MIT, NYU, Northwestern, Penn, Stanford, UCLA, Washington University in St. Louis, and conference participants at the AEA 2019 Annual Meetings, the Macro Financial Modeling Winter 2019 Meeting, the SED Day-Ahead Conference 2019, and the NBER Summer Institute Asset Pricing Meeting. We thank our data provider for use and explanations of their data and Yijun Liu for research assistance. Data were obtained under a nondisclosure agreement with a financial institution. All authors are consultants for the large financial institution, but only Duncan Simester receives financial compensation. The views expressed herein are those of the authors and do not necessarily reflect the views of the National Bureau of Economic Research.

NBER working papers are circulated for discussion and comment purposes. They have not been peerreviewed or been subject to the review by the NBER Board of Directors that accompanies official NBER publications.

(C) 2018 by Maarten Meeuwis, Jonathan A. Parker, Antoinette Schoar, and Duncan I. Simester. All rights reserved. Short sections of text, not to exceed two paragraphs, may be quoted without explicit permission provided that full credit, including $\left({ }^{\circ}\right.$ notice, is given to the source. 
Belief Disagreement and Portfolio Choice

Maarten Meeuwis, Jonathan A. Parker, Antoinette Schoar, and Duncan I. Simester

NBER Working Paper No. 25108

September 2018, Revised June 2021

JEL No. D14,D84,E71,G11,G12,G40

\begin{abstract}
Using proprietary portfolio data on millions of households, we show that (likely) Republicans increase the equity share and market beta of their portfolios following the 2016 presidential election, while (likely) Democrats rebalance into safe assets. We provide evidence that this behavior is driven by investors interpreting public information using different models of the world, by ruling out the main non-belief-based channels (like income hedging needs, preferences, local economic exposure) using detailed controls for ex ante wealth and investments, demographics and income, and even county-employer-period fixed effects. These findings are driven by a small share of investors making big changes in allocation, and are stronger among investors who are more attentive to their portfolios or who do not delegate their investment decisions.

Maarten Meeuwis

Washington University in St. Louis

Olin Business School

One Brookings Drive

Campus Box 1133

St. Louis, MO 63130

m.meeuwis@wustl.edu

Jonathan A. Parker

MIT Sloan School of Management

100 Main Street, E62-642

Cambridge, MA 02142-1347

and NBER

Antoinette Schoar

MIT Sloan School of Management

100 Main Street, E62-638

Cambridge, MA 02142

and NBER

aschoar@mit.edu

Duncan I. Simester

Sloan School of Management

MIT E62-542

100 Main St

Cambridge, MA 02142-0679

simester@mit.edu
\end{abstract}

JAParker@MIT.edu

A online appendix is available at https://www.nber.org/data-appendix/w25108/ 
The canonical assumption in most economic models is that people have rational expectations with common priors. However, in both the laboratory and the real world, people tend to report different probabilities for the same event, and update these reported beliefs differently in response to common information. ${ }^{1}$ A leading interpretation of this evidence is that people believe in different models of the world - they hold different possibly dogmatic priors - which leads them to disagree both about baseline probabilities and about the implications of common information for future outcomes. However, a major challenge in testing this proposition outside of artificial laboratory environments has been to identify and measure behavioral responses that come from changes in beliefs separately from behavioral responses that come through other economic channels or are driven by other dimensions of preferences. ${ }^{2}$ In this paper, we test this proposition not by inferring beliefs from reported beliefs or asset prices, but by showing that investors adjust their portfolios differently in response to the same public event and by ruling out the main non-belief channels through which the event may have caused this behavior.

Specifically, we posit that a person's political affiliation measures the model of the world that they use to interpret the economic impact of political outcomes. We then study portfolio differences by political affiliation (inferred from zip code) using anonymized, proprietary data on millions of Retirement Investors, defined as retail investors with retirement savings accounts in the middle $80 \%$ of the age-adjusted distribution of retirement wealth. ${ }^{3}$ Consistent with Republicans (Democrats) reporting to become more optimistic (pessimistic) about future US economic performance following the US national election of 2016, we show that (likely) Republicans rebalance their portfolios towards equity, while (likely) Democrats rebalance their portfolios towards relatively safe assets after the unexpected outcome of the election, both over a six to nine-month horizon following the election.

The key challenge for identifying the role of beliefs in this portfolio rebalancing is that, even if investors held common priors and updated rationally, the real impact of the election could still differentially change their hedging needs or overall wealth levels. For example, Republican and Democratic voters tend to work in different industries and live in different parts of the country so that their future incomes and costs of living might be differentially affected by the election. ${ }^{4}$ Such economic differences could generate different behavior not driven by beliefs. Previous research (discussed subsequently) has documented both differential economic impacts of election outcomes and a relationship between reported beliefs and behavior. Our key contribution (along with more

\footnotetext{
${ }^{1}$ Brunnermeier et al. (2021) surveys both the research on, and importance of, non-rational beliefs for asset returns.

${ }^{2}$ We follow the Savage, revealed-preference terminology, and use the term preferences to refer to the elements of investor objective functions that are distinct from the beliefs that represent subjective probabilities about realizations of states.

${ }^{3}$ Retirement investors make up $40 \%$ of US households, and hold $47 \%$ of total retirement wealth and $41 \%$ of all household investable wealth (see Section III).

${ }^{4}$ As in Pastor and Veronesi (forthcoming) and Autor et al. (2020).
} 
accurate measurement) is that we rule out the main channels through which the election may have differentially impacted individuals' portfolio behavior other than through beliefs.

Our main finding is that (likely) Republicans increase the equity share and market beta of their portfolios relative to otherwise similar (likely) Democrats, even conditional on detailed controls both for ex ante differences in preferences and endowments and for ex post differences in local economic conditions and income hedging needs. That is, differences in portfolio rebalancing between Republican and Democratic voters following the election are not explained by differences in ex ante wealth, income, age, or characteristics of portfolios. More importantly, rebalancing is also not explained by differential exposure to regional or firm-level policies due to the election outcome: we find different investment behavior comparing investors working at the same employer and living in the same county (that is, after controlling for county-employer-period). Further, these changes in portfolio holdings arise from active rebalancing, net of any differences in passive portfolio appreciation. Finally, the outcome of the 2016 election was an unlikely event, the policy differences between presidential candidates were large, and the portfolio share of equity moves similarly for Republicans and Democrats in the year prior to the election, all suggesting that the differential rebalancing is a response to the election rather than other differences correlated with party affiliation.

Having controlled for the main channels through which rational theories operate, we conclude that this rebalancing behavior is due to differential updating of beliefs about the expected return of stock market investments, likely through the performance of the US economy. Consistent with this interpretation, people affiliated with either party report little change in their views about their own individual economic situations, but report updating significantly differently by party about macro-level economic prospects, consistent with Huberman et al. (2018). However, we cannot reject that arbitrary preference variation by party affiliation drove the differences in both reported beliefs and investment behavior. ${ }^{5}$

Quantitatively, the average effect of the election on portfolio allocations grows slowly over months following the election. Ultimately, the quintile of most Republican zip codes increase the equity shares of their portfolios by roughly half a percent relative to the quintile of most Democratic zip codes. This relatively small average result masks substantial heterogeneity. Most of the investors that we observe do not rebalance at all; only a third of investors actively change their portfolio in any given year and only a tenth of investors change their allocations across asset classes (consistent with the passivity documented in Madrian and Shea (2001) and Choi et al.

\footnotetext{
${ }^{5}$ Revealed preference theory implies that it is impossible to separate arbitrary preferences variation from beliefs. As an example, our findings could be due to Republicans and Democrats consuming different bundles of goods which have prices that are differentially exposed to the outcome of the election even after conditioning on observable factors. For instance (as suggested by a referee), gun control policies could affect the costs of firearms for those who have preference for owning guns.
} 
(2004)). Among the investors who do rebalance, the election had a much larger effect. For those investors who active reallocated their portfolios during the year before our main sample starts, the effect of the election on equity share is three times as large. More strikingly, seventy-five percent of our effect comes from investors who change the equity share of their portfolio by more than twenty-five percent after the election.

This heterogeneity in responses varies by how actively investors are engaged in their portfolio choices. Wealthier and older investors, who tend to be generally more attentive to managing their savings, rebalance more strongly in response to the election. And investors who delegate more who have a larger fraction of their wealth invested in automatic investment products such as target date funds or accounts managed by an advisor - rebalance by less in response to the election. Our results are in line with the attenuation puzzle - the low correlation between portfolio holdings and reported beliefs - documented in Ameriks et al. (2020), and the finding that changes in reported beliefs do not predict the likelihood of trading but do predict the direction of trading conditional on a trade, documented in Giglio et al. (forthcoming).

As corroborating evidence that differential updating of beliefs drives portfolio behavior, we follow Curtin (2017) and show that Republicans in University of Michigan Survey of Consumer Confidence (SCC) report becoming much more optimistic about the future of the US economy following the 2016 US national election, while Democrats report becoming more pessimistic. ${ }^{6}$ This pattern of reported beliefs is consistent with a substantial literature documenting that political affiliations lead people to report that they interpret public news differently. ${ }^{7}$

Our results also provide some validation that survey-reported beliefs on the macroeconomy contain substantial information about true beliefs that are independent of people's individual economic situations or preferences. An influential literature (described in Section II) shows that survey-reported beliefs correlate with financial behaviors. By identifying a specific event that changes beliefs and controlling for the main alternative channels through which the event could have changed portfolios other than through beliefs, we confirm that heterogeneous beliefs are a major factor driving both survey responses and differential portfolio allocations.

Our results support models in which people agree to disagree even in asset markets where prices convey information. In a back-of-the-envelope calculation, we show that the change in beliefs and behavior induced by the 2016 election has a small quantitative effect on the net demand for stocks, on the order of a few billion dollars. As noted, the rebalancing we find occurs over

\footnotetext{
${ }^{6} \mathrm{~A}$ different type of corroborating evidence is provided by research showing that "sentiment" is correlated with risk-taking (e.g. Edmans et al., 2007; Kamstra et al., 2003; Hirshleifer and Shumway, 2003) if one interprets sentiment as subjective expected present discounted utility rather than emotional risk tolerance.

${ }^{7}$ Bartels (2002) and Gaines et al. (2007) document a partisan bias in perceptions of changes in economic performance and military outcomes, and Alesina et al. (2018) shows that political party affiliation determines how new information differentially changes reported beliefs. Subsequent work studies the roles of selective exposure, selective attention, motivated processing, and respondent bias (cheerleading) and incentives (Prior, 2007; Prior et al., 2015; Bullock et al., 2015).
} 
many months following the election, consistent with investors being aware that asset prices do not rapidly incorporate their party-specific beliefs and so knowing that they need not react immediately to this change in beliefs. As additional evidence that supports the predictions of theoretical models with heterogeneous (non-Bayesian) updating of beliefs (Miller, 1977; Harris and Raviv, 1993; Harrison and Kreps, 1978; Morris, 1996; Scheinkman and Xiong, 2003; Banerjee and Kremer, 2010; Simsek, 2013), we show that the total amount of trading among the investors in our sample rises following the election. Rational expectations models of asset prices have been largely unable to match portfolio heterogeneity and the volume of trading. ${ }^{8}$

While there are many existing approaches to modelling differences in beliefs, our results are most directly supportive of models that link heterogeneity in beliefs to identity. ${ }^{9}$ In particular, building on Akerlof and Kranton (2000), Bénabou and Tirole (2011) develops a model of stakedependent beliefs in which people's investment choices are affected by what their allocations would imply about their political beliefs. In this interpretation, the election made political identity more salient and solid for Republicans (more fragile for Democrats), and so led to portfolio reallocation to equities (safer assets for Democrats). By controlling for county of residence we control for differences in the supply of information, like differences in local newspapers or access to cable news. Thus our findings are consistent with differences in beliefs being "deep" like identity and causing differences in information sources rather than the reverse.

Related literature While there is growing literature on the effect of political polarization in the United States on both economic outcomes and reported beliefs, prior papers have found inconclusive or no results on how elections affect household behavior. Most closely related to our paper, Bonaparte et al. (2017) finds no significant or stable correlation during 1988-2000 between investors' party affiliations and the equity shares of their portfolios using self-reported data from the National Longitudinal Survey of Youth. ${ }^{10}$ Kaustia and Torstila (2011) shows that left-wing voters in Finland are less likely to hold stocks than right-wing voters, but again without controlling for differences in the exposure of labor income or local economic performance to political risks. We advance this line of research both by studying an historically large political shock and by using much larger and more detailed administrative data on millions of typical investors so that we control for the main direct channels through which changes in policies could differentially impact

\footnotetext{
${ }^{8}$ The variation in portfolio positions and the volume of trade in assets are significantly underestimated by quantitative rational expectations models (Guiso et al., 2002; Calvet et al., 2007; Curcuru et al., 2010). Barber and Odean (2008) documents the transaction cost of over-trading among a sample of active traders.

${ }^{9}$ Examples of more general models include Brunnermeier and Parker (2005), Hansen and Sargent (2010), Gennaioli and Shleifer (2010), and Mailath and Samuelson (2020) for example.

${ }^{10}$ Using account-level data from a brokerage firm, Bonaparte et al. (2017) also finds differences in the composition of equity held related to differences in party affiliation, but without controlling for possible differences in real economic exposure that should also cause such differences. We find no evidence of differential changes in the composition of equity held in our data.
} 
investors. Our work is also related to papers that document differences in professional behaviors by political affiliation (Hong and Kostovetsky, 2012; Kempf and Tsoutsoura, forthcoming). Also consistent with our findings but using professional situation as a measure of people's different models of the world, Linnainmaa et al. (2021) shows that professional portfolio advice correlates with personal portfolio choices across investment advisers (see also Cheng et al., 2014). Again, our contribution is to rule out many ways in which rational theories could rationalize observed differences in behavior unrelated to differences in beliefs.

Our results are also related to research showing that investors seem to incorrectly update in response to idiosyncratic or private information, typically by over-weighting information from their own past experiences or friends (Grinblatt and Keloharju, 2000; Vissing-Jørgensen, 2003; Malmendier and Nagel, 2011; Cookson and Niessner, 2020; Bailey et al., 2018).

There is also ongoing research on whether local aggregate consumer spending responds differently to electoral outcomes depending on the dominant local political affiliation (e.g. Gerber and Huber, 2009, 2010; Mian et al., forthcoming). These analyses focus on measuring local aggregate effects, and do not look to separate the beliefs channel from differences in real economic effects. We contribute (a little) to this literature by analyzing the role of beliefs in differences in saving rates in Section IX.A.

Finally, our paper also contributes to an older literature providing indirect evidence that investors interpret public signals differently. The volume of asset trading rises after public signals (e.g. Kandel and Pearson, 1995), survey beliefs or stated forecasts widen (e.g. Bamber et al., 1999; Carlin et al., 2014), and stock prices move in predictable ways (see the survey Hong and Stein, 2007) that are correlated with economic disagreement ( $\mathrm{Li}$ and Li, 2021).

\section{The 2016 US Election}

The 2016 US national election is almost uniquely suited for measuring how households who believe in different political models of the world update in response to a publicly observable signal. First, the outcome of the 2016 national election was a very public event. ${ }^{11}$ Thus, our results are unlikely to be due to differences in attention. Conditional on observing the outcome, households may process the information at different speeds or take different amounts of time to act, but there is no ex ante reason to believe that this differs by party affiliation.

Second, this election was not correlated with other significant events. Such a correlation would weaken our claim that the differences we uncover are due to different interpretations about a given piece of news about future economic policies and performance.

\footnotetext{
${ }^{11}$ While the outcome of the presidential race was highly unlikely and the main news revealed by the election, we measure the effect of all the electoral outcomes including for example the fact that the Republican party won a majority in the US Senate, an event with roughly even odds prior to the election.
} 
Third, this presidential election, and the Republican party achieving a majority in the Senate, constitute a very large and unexpected change in likely future US economic policy. While all presidential elections affect policy, the 2016 election involved two candidates with quite different policy prescriptions. More importantly, the outcome of the election was unexpected. For most other types of news about the economy or other changes in governance, such as most elections, legislation, and court decisions, information percolates slowly into the economy and the timing of its arrival is hard to pinpoint.

For a measure of the probability of the outcome of the presidential election, we consider the market prices of two contracts traded on Betfair that pay $\$ 1$ conditional on the respective party winning the election. State prices of course reflect marginal utilities as well as probabilities, but Betfair is a UK-based internet betting exchange and because of US regulations, it is hard for American investors to enter this market. ${ }^{12}$ Thus, these prices differ from probabilities only to the extent that the marginal utility of the UK investors is different across outcomes of the US presidential election. The market predicted a Democratic victory the entire year before the election and with roughly $75 \%$ likelihood during the six months prior to the election rising to over $80 \%$ on the eve of the election (see Appendix Figure A.1). This stability contrasts slightly with polling data (which is survey-based hypothetical choice data) which has larger swings around events like national conventions and in which the odds appeared close to even at times.

Fourth, we can use differences in political affiliation as ex ante measures of differences in investors' models of the world. This measure is not derived from any economic behavior like portfolio allocation, for which differences might be directly due to differences in preferences like risk aversion or differences in income dynamics and resulting hedging needs. That said, a correlation between political affiliation and preference or hedging needs is of course possible, since beliefs about the economy are not randomly assigned but form endogenously. So our analysis will provide evidence that while there are ex ante differences in the portfolios of Republicans and Democrats on average, the changes in portfolio allocations in response to the election are not driven by these ex ante differences in economic exposure. ${ }^{13}$ A related benefit is that we can use other household-level data that measures political affiliation to show how household responses differ along other dimensions, and in particular, we present evidence on survey measures of economic beliefs in Section II.

All four features of this event are important for our study and important to consider in any

\footnotetext{
${ }^{12}$ Alternative sources of betting market data on elections are Intrade, the Iowa Electronic Market (IEM), and PredictIt. Intrade shut down in 2013. IEM is open to US households but is capped at $\$ 500$ and does not trade a contract on the outcome of the election (only contracts based on vote shares). PredictIt also has capped trading, and like the IEM, is relatively small.

${ }^{13}$ It is also the case that political affiliation may be associated with different views of the likelihood of the outcomes of the 2016 election or the policies that are implemented conditional on the outcome. These are subsumed into what we measure.
} 
study of the relationship between beliefs and behavior. In our case, people of different party affiliations are continually responding to all sorts of information and changes in their economic environment. And our hypothesis is that they are responding differently maybe along many dimensions of identity. Without the ability to differentiate households ex ante and without a large, public signal, we could not separate the belief-driven portfolio response of households to the election from the effects of other factors. ${ }^{14}$

\section{Reported Beliefs}

Prior research shows that Republicans and Democrats interpret political events differently and that this leads to different reported economic expectations. ${ }^{15}$ This section builds directly on Curtin $(2016,2017)$ which shows that in the University of Michigan Survey of Consumer Confidence (SCC), Republicans report much more optimism about the economy following the election while Democrats report more pessimism. ${ }^{16}$ We use both the usual monthly data on reported economic expectations in the SCC and special questions that the survey added about political affiliation from June to October 2016 and from February to April 2017. The survey does not contain zip code or county of residence, nor can we replicate the sample of RIs in the SCC, so instead we analyze the subsample of households that hold stocks ( $63 \%$ of the sample weighted, $65 \%$ of the sample unweighted). The results are nearly identical for the entire SCC sample.

Our first result is that the election appears to have a dramatic effect on expectations of future national economic performance. Figure 1a shows the average response among people with different party affiliations to the question "Looking ahead, which would you say is more likely - that in the country as a whole we'll have continuous good times during the next 5 years or so, or that we will have periods of widespread unemployment or depression, or what?" and we index the answers as Good times $=5$, Good with qualifications $=4$, Pro-con $=3$, Bad with qualifications $=$ 2 , and Bad times $=1$. On average, Republicans change from slightly pessimistic before the election to highly optimistic after, and Democrats the reverse. Confirming this difference, Figure $1 \mathrm{~b}$ shows the same large changes in expectations of the unemployment rate in a year. The reported large changes in beliefs about future national economic performance generate a desire to change exposures to national economic performance in investment portfolios.

Our second result is that there are no similar large changes in people's reported expectations

\footnotetext{
${ }^{14}$ To the extent that the arrival of other information also causes households with different political affiliations to behave differently, then it will bias our measured responses. How big is this bias? As we show, during the period before the election, the portfolios of households of different political affiliations behaved similarly, consistent with the arrival of little political news or other news that might be differentially interpreted. See our discussion in Section IV.

${ }^{15}$ See Conover et al. (1987); Bartels (2002); Gaines et al. (2007); Gillitzer and Prasad (2018); Alesina et al. (2018).

${ }^{16}$ Das et al. (2020) finds that reported beliefs about future macroeconomic outcomes are persistently different by socioeconomic status.
} 
about their own economic circumstances. Figure 2a plots by party affiliation the average answer to: "During the next 12 months, do you expect your income to be higher or lower than during the past year?" Democrats are more likely to expect higher income before the election, but the advantage is small. Following the election, Republicans on average have higher reported expectations and Democrats lower, but the changes are moderate and the ultimate differences small. In contrast, Figure $2 \mathrm{~b}$ shows the changes in expectations of whether business conditions overall will be better or worse in a year and shows a much larger swing. This result suggests that changes in people's behavior after the election are due to changes in beliefs about the aggregate economy and not responses to changes in beliefs about their own individual economic situations, such as changes in expected labor income that might make them more or less likely to invest in equity.

\section{Data}

\section{III.A Party Affiliation}

The particular measure of different models of the world that we use is political party affiliation. Our main measure of likely political affiliation is based on publicly available data on individual campaign donations during the 2015-2016 election cycle from the Federal Election Commission aggregated to the zip code level. We restrict attention to contributions from individuals to political action committees associated with the two main parties or with their presidential nominees and with at least \$20 million in donations (see Appendix A.1 for further details). For each zip code, we count the number of donors to each party. ${ }^{17}$ We limit our analysis to zip codes with at least 10 donating individuals and measure the Republican contribution share of a zip code as the number of donors to the Republican party or the Republican presidential nominee divided by the total number of donors in that zip code. Appendix Figure A.2 shows the geographical distribution of the Republican contribution share.

For robustness, we also confirm that our results hold for three alternative measures of likely political affiliation. First, we consider the dollar-weighted version of Republican contribution share defined as the dollars donated to the Republication party or the Republican presidential nominee divided by the total amount donated in that zip code to either party. Second, we use data on votes for the presidential election at the county level and define the Republican share of a county as the number of votes for the Republican candidate divided by the total number of votes to both parties' candidates. ${ }^{18}$ Appendix Figure A.3 shows that the Republican contribution share and Republican vote share line up well at the county level, despite the limited number of individuals that make in-

\footnotetext{
${ }^{17}$ We find that donations weighted by people are more precise and more differentiating than donations weighted by dollars. Our hypothesis is that this is because the value-weighted donations measure is sensitive to outliers; a single wealthy donor can swing the measure for the whole area.

${ }^{18}$ Data are from David Leip's Atlas of U.S. Presidential Elections at uselectionatlas.org.
} 
dividual contributions (the median coverage by zip code is $0.3 \%$ of the population). Finally, we use county-level vote shares for the Republican presidential candidate in the 2012 election (eliminating any sui generis effects of particular candidates in 2016). All of our measures surely have some mismeasurement. To the extent that mismeasurement is classical, our main results are attenuated.

\section{III.B Household Portfolios}

Our main data are anonymized, account-level data on financial holdings from a large US financial institution. We have access to anonymized information on all accounts held directly at the firm by individual investors. For these accounts, we observe end-of-month account balances and holdings, and all inflows, outflows, and transfers at a daily frequency. We observe assets at the security level (identified by CUSIP) for $92 \%$ of wealth. For the remaining $8 \%$ we observe the characteristics of the fund the wealth is invested in. We aggregate all accounts - pre-tax, taxable, and untaxed across all members of a household and track household portfolios. ${ }^{19}$ The data cover millions of households and trillions of dollars in financial wealth.

We also have access to some information on the characteristics of the investors themselves. In addition to wealth information on all households, we observe age, gender, marital status, and zip code for the vast majority of individuals. ${ }^{20}$ We define the head of the household by selecting the individual with the highest total assets (or the older individual if all assets are jointly held), and we use the head's characteristics as that of the household for non-financial information like age and for employment information. We can construct an employer indicator variable for a substantial subset of households. In addition, we use the employer's NAICS code to assign each such household to a three-digit industry. For a subset of these households, we also observe annual labor income of the head of household. Our main sample uses information from one year before to one year after the election, from October 31, 2015 to October 31, 2017.

While this data provides a unique view of retirement savings and the portfolio allocations of US households, there are two potential weaknesses of our data. First, while we observe a significant share of US households, this is obviously not a randomly selected sample. In particular, most observed household wealth is retirement savings and few households have a very high net worth (as we document subsequently). Our analysis does not require a random sample, but we would like to understand the relationship between our sample and the US population. The second potential weakness is that we do not necessarily observe all the investable wealth of the households in our sample. One way this occurs is that we only observe one member of the household for some

\footnotetext{
${ }^{19}$ Where there are multiple households that co-own a given retail account, we assign each account to a single individual by selecting the (oldest) owner with the highest total assets. This yields a unique mapping from investment accounts to households.

${ }^{20}$ The firm data include some variables obtained through a commercial consumer database. Part of the data on marital status comes from this database and we treat entries that were not collected at the household level as missing.
} 
households. The other is that some households have investable wealth at other institutions.

To address these issues, we select a subsample of our data that meets a set of criteria that is likely to be reasonably representative of the US population that also meets this set of criteria. We focus on households with moderate levels of retirement wealth, which we call retirement investors (RIs). Specifically, we define RIs as households of working age - heads of households between the ages of 25 and 64 - without extremely high or low retirement wealth, defined as all wealth in retirement saving accounts of all types (excluding defined benefit plans and Social Security).

We use the 2016 Survey of Consumer Finances (SCF) to understand how the population of RIs compares to the US population and how well the wealth and portfolio holdings of the RI subsample of our account-level data compare to the RI subsample in the US. We focus on households with some retirement wealth. Using the 2016 SCF, we run quantile regressions of the log of retirement wealth on a second-order polynomial in age. We then drop households with retirement wealth below the estimated 10th percentile or above the 90th by age. This RI subsample of the SCF captures $31.4 \%$ of the US population, $32.0 \%$ of retirement wealth, and $24.8 \%$ of investable wealth held by households in the US according to the $\mathrm{SCF}^{21}$ Investable wealth is defined as money market funds (MMFs), non-money market funds, individual stocks and bonds, quasi-liquid retirement wealth, and other managed accounts. ${ }^{22}$ Figure 3 shows the wealth distributions of the US population and of our subsample in the 2016 SCF.

Applying the same cutoffs to our data provides a sample of millions of investors and well more than a trillion dollars in investable wealth. ${ }^{23}$ The first panel of Figure 4 shows that the retirement wealth distribution of our RI sample of households lines up well with that measured by the SCF. The second panel of Figure 4 shows that our data also match reasonably well the distribution of total investable wealth in the SCF, but that our data is missing some non-retirement wealth mainly for households with more than $\$ 500,000$ in investable wealth.

To characterize portfolio risk taking, we classify fund and security holdings into equity, bonds,

\footnotetext{
${ }^{21}$ The age cutoff selects $69.7 \%$ of the US population, $65.8 \%$ of retirement wealth, and $58.3 \%$ of investable wealth according to the SCF. Within the 25-64 age group, RIs are $45.1 \%$ of the population and hold $48.6 \%$ of retirement wealth (roughly $50 \%$ of retirement wealth is held by the top 10 percent) and $42.6 \%$ of investable wealth. For age 30 , the 10 th and 90th percentile cutoffs are roughly $\$ 1,500$ and $\$ 75,000$, and for age 64 they are roughly $\$ 8,000$ and $\$ 1,000,000$.

${ }^{22}$ In the SCF, "other managed accounts" includes personal annuities and trusts with an equity interest and managed investment accounts. Excluded categories of financial wealth are checking and savings accounts, saving bonds, certificates of deposit, cash value of life insurance, and other financial assets.

${ }^{23}$ For use in our sample, because we select our sample at the initial date October 31, 2015, we first translate the retirement wealth cutoffs from the SCF at the end of 2016 to cutoffs at the initial date by matching the corresponding quantiles of retirement wealth in our dataset between the two dates. We perform two additional screens in our sample. First, we select households with at least $50 \%$ of investable wealth in observable portfolio assets. Because of account types, we cannot measure characteristics like market exposures for a limited set of assets. Average holdings in these assets are less than $1.3 \%$ of total investable wealth. This restriction excludes only $1.0 \%$ of households in our RI sample. Second, we limit ourselves to households that have portfolio holdings between $20 \%$ and $500 \%$ of initial assets in every month ( $83 \%$ of the full sample). This gives us a balanced panel and drops people who start or stop using the firm during this period.
} 
cash, and alternative assets (e.g. real estate and precious metals). ${ }^{24}$ We calculate market betas by regressing fund and security excess returns on the market excess return over the period 2006-2019, requiring at least 24 months of return observations. We also use other security-level information, such as international and sector exposures. The details are in Appendix A.2.

Column 1 of Table 1 shows the details of the portfolios held by our RI sample, as of just prior to the election shock. Our average RI has $\$ 138,100$ in investable wealth, of which 84 percent is in retirement accounts. More than seventy percent of wealth is invested in equity (the sum of directly held equity, equity funds, and the equity amount of funds that invest across asset types), and the portfolios have an average market beta of 0.74 ( 0.72 if households are weighted by wealth). The second column of Table 1 shows that, relative to the estimates from the SCF, our data capture most retirement wealth of RIs but, while we match median total investable wealth well, our data misses the mean of non-retirement investable wealth, primarily due to missing wealth among high net worth households (see Figure 4).

Column 1 of Table 2 shows that the average age of household heads in our RI sample is 46 years old, $44 \%$ of household heads are female, and 73\% are married. Our sample of working age households has a similar age distribution as the corresponding SCF sample of RIs (see Appendix Figure A.4). The average household income is $\$ 101,200$ and the median is $\$ 77,300$.

Figure 5a shows a scrambled map of the share of households in each US county that are in our sample of RIs: we calculate the population share of households that are in our sample by county, and then randomly reallocate the shares across counties in each state to preserve anonymity. Figure $5 b$ shows the density of the share of the population in each county that is in our RI dataset. We remind the reader that RI households represent only a third of the US population (according to the SCF) and that we are using the term household when we in fact may only observe one of two (or more) earning and investing members.

Finally, we use each investor's zip code of residence one year prior to the election to link investors to our zip code or county measures of political party affiliation. Our sample is tilted towards households that live in Democratic zip codes according to our contributions measure. ${ }^{25}$

Tables 1 and 2 show the distribution of asset holdings and demographics by party affiliation of the zip code of the households just prior to the election. There are differences across zip codes associated with party affiliation, but they are generally small. The average equity share varies by less than a percent across groups, with Democratic zip codes having slightly higher equity shares on average. The differences are even smaller for the average market beta of investor portfolios.

\footnotetext{
${ }^{24}$ Holdings in alternative assets are on average less than $1 \%$ of total assets and we do not separately analyze this investment class.

${ }^{25}$ Appendix Figures A.5a and A.5b show the distribution of our households across areas with different political affiliations. While in the regression analysis all households are weighted equally, in the graphical analysis we construct groups symmetrically around the $50 \%$ mark. The findings are consistent.
} 
Nevertheless, in our analysis, we control for pre-election equity share, as well as many individual demographic characteristics.

While both the share of equity and the market beta of the portfolios of households with different political affiliations are quite similar prior to the election, we do find some differences in the composition of equity holdings. While equity portfolios are similar across zip codes in terms of market betas, the share allocated to funds, and the share of international equity holdings, there are differences in the sectoral composition of stock holdings and in particular with respect to industry performance immediately following the election. ${ }^{26}$ Although allocations to specific sectors are a limited fraction of overall portfolios, we find that households in zip codes with different predominant political affiliations hold significantly different exposures to winning and losing sectors. Table 1 shows that the most Republican zip codes hold on average $6.5 \%$ of their total equity in winning sectors, relative to $4.8 \%$ for the most Democratic zip codes. For losing industries, the picture is reversed with the most Democratic zip codes holding more than $4.7 \%$ of their equity in losing industries and the most Republican zip codes holding less than 3.5\%.

Given these differences it is important that our analysis in the next two sections shows that these ex ante sectoral differences in portfolio holdings do not explain our findings of differential post-election movements in equity shares, trading, and portfolio betas by party affiliation. We do this in three ways. First, we control for these differences in ex-ante portfolio compositions in regression analysis. Second, we analyze price-constant portfolios that exclude all post-election differences in returns from portfolios. Third, this difference in holdings is significantly due to people over-weighting their employer's stock in their portfolios, and much of our analysis compares workers at the same firm.

\section{Household Portfolio Reallocation}

This section shows that likely Republican households increase the exposure of their portfolios to US economic growth after the 2016 presidential election relative to likely Democratic households. We show that this effect is not driven by passive appreciation and is driven by trading of households that are actively reallocating their portfolios. The next section builds the case that this effect is caused by differential updating of beliefs by showing that this finding is robust to many controls for differences in preferences or hedging needs across households.

\footnotetext{
${ }^{26}$ We use Global Industry Classification Standard (GICS) codes to measure exposure to different sectors. We use the Morningstar benchmark for sector mutual funds and Compustat/CRSP for directly-held equity. The sectors are energy, materials, industrials, consumer discretionary, consumer staples, health care, financials, information technology, telecommunication services, utilities, and real estate. We classify an industry as a winner or loser from its stock market response from the end of October through to the end of 2016. The winning industries are financials, telecommunication services, energy, materials, and industrials, while the losing ones are consumer staples, utilities, information technology, health care, and real estate. Consumer discretionary is in the middle and is considered neither.
} 
To begin, we simply plot the data. Figure 6 shows the change in the average portfolio share of equities (relative to October 31, 2016) for households in zip codes with different shares of contributions to each party, relative to their baseline shares at the end of October 2016. Figure 6a displays equally-weighted portfolio shares, Figure $6 \mathrm{~b}$ displays the value-weighted portfolio shares, which sum the value of equity across all households in each group before dividing by total investable wealth for that group.

First, for all groups, the share of wealth invested in equities decreases prior to the election, which suggests that something caused reduced investment in the stock market regardless of party affiliation. ${ }^{27}$ This rebalancing might have been election-related - due, for example, to information revealed during the political race or the approaching uncertainty of the election - or it could simply represent rebalancing after a half decade of relatively good stock market returns. After the election, the equity share rebounds for all groups, primarily due to high stock market returns).

Second, and our main result, the share of wealth invested in equities rises in predominantly Republican zip codes relative to predominantly Democratic zip codes following the election. Specifically, households living in Republican zip codes increase their equity exposure by roughly $0.4 \%$ percent of their wealth relative to those in the most Democratic zip codes, consistent with increased optimism about the economy by Republicans relative to Democrats.

Third, there are minimal differences in the evolution of the portfolio shares in equity across areas with different political affiliations prior to the election. During this time, there is information arriving about the likely outcome of the election, but the total change in probability over this period prior to the election is smaller than that on the one day of the election (see Appendix Figure A.1). The similarity of the movements in the equity share before the election is consistent with our evidence that there are only small prior differences in equity shares across zip codes with different political leanings. These zip codes are surely not the same, but are also not affected very differently by economic news (and the limited political news) in the year prior to the election. ${ }^{28}$

We find similar results for long bonds and cash-like securities. Households in zip codes that are predominantly Republican decrease the shares of their portfolios invested in both bonds and cash-like assets (including MMMFs) following the election relative to those in zip codes that are predominantly Democratic (see Appendix Figures A.6 and A.7).

One concern with these results so far is the possibility that these movements may be due to inactivity, initial differences in holdings, and appreciation resulting from the post-election stock market increase following the election. Republicans may hold more equity or equities with higher

\footnotetext{
${ }^{27}$ Roughly two thirds of the pre-election decline comes from allocation decisions of households (see Figures 8a and A.10). Post election, allocation decisions on average are equity neutral.

${ }^{28}$ Figure 6a does show a small rise in equity share in Democratic zip codes relative to Republican zip codes prior to the election, which is consistent with the slowly increasing probability of a Democratic victory in the presidential election during this period.
} 
beta, and so might have had a disproportionate increase in the equity share of their portfolios due to the post-election increase in stock prices. Like most wealth for the typical American household, the majority of the wealth that we observe is retirement wealth which is notably "sleepy." While we address these concerns in a regression framework subsequently, we present three transparent pieces of evidence that reject this hypothesis here.

First, we find larger differential effects by party affiliation when we focus on households that are more active in the past, where an "active" household is defined as one that had at least one monthly portfolio reallocation due to trading that changed the equity share by at least $5 \%$ (in absolute value) during the year November 2014 to October 2015 (the year prior to our main sample). This sample is 11.1 percent of our original sample (see Table 2). Figure 7a shows that active investors in mostly Republican zip codes have a much larger relative increase in equity share after the election, on the order of $1.5 \%$ of their investable wealth on average. (Appendix Figures A.8a and A.8b show the corresponding plots for long bonds and safe assets, respectively, for the sample of active investors.) These effects translate into differences in the overall market betas of portfolios by likely political affiliation. Figure $7 \mathrm{~b}$ shows that movements in market betas of active investors are also very similar prior to the election across political affiliations, and diverge post election, with market beta rising relatively more in Republican zip codes post election.

Second, we measure the difference in active rebalancing in two different ways. The composition of an investor's portfolio is changed by revaluations, reallocations, and inflows and outflows related to deposits and withdrawals. We measure rebalancing into equity by focusing on changes in equity share driven by either transfers of assets into or out of equity or withdrawals or inflows that change equity shares.

Our first method to measure rebalancing is simply to construct and track hypothetical portfolios as if there were no changes in valuations of funds or securities. Figure 8a plots the equity share of these hypothetical price-constant portfolios and shows that prior to the election, households are rebalancing out of equity in a nearly identical way across the distribution of zip codes by political affiliation. After the election, Republican zip codes actively increase their equity shares by reallocating wealth from safe assets into equity, while primarily Democratic zip codes decrease their equity shares by reallocating wealth out of equity into bonds and cash. The total reallocation is roughly the same size as the total difference shown in Figure 6. Note that in Figure 8a we also observe mostly Republican zip codes reducing their equity shares slightly more than other zip codes over the year prior to the election, which is consistent with the small amount of news that comes out pre-election as the chances of a Democratic victory rise. Figure 8b again shows similar patterns for market betas before and after the election. (Appendix Figures A.9a and A.9b show the corresponding plots for long bonds and safe assets, respectively, of price-constant portfolios.)

It is worth noting that while Figure 6 shows that party affiliation and the election do not explain 
much of the temporal variation in zip code between the most Republican and most Democratic zip codes, most of this is due to passive behavior and market returns. Removing market return, Figure 8 a shows a much higher share of the temporal variation in equity share between these groups is driven by political variation in beliefs.

Second, we measure excess equity trading for household $i$ in month $t$ as

$$
\text { Excess Equity } \text { Trades }_{i, t}=\frac{\text { Equity Trades }_{i, t}-\text { Equity Share }_{i, t-1} \text { Total Trades }_{i, t}}{\text { Assets }_{i, 0}},
$$

where Equity Trades $_{i, t}$ is the sum of all transactions in equity securities by household $i$ in month $t$ (positive if buying, negative if selling), Equity Share ${ }_{i, t-1}$ is the equity share at the end of month $t-1$, Total Trades $i, t$ is the sum of all transactions in all securities by household $i$ in month $t$, and we scale by initial household assets, Assets $_{i, 0}$. Appendix Figure A.10 shows cumulative excess equity trades from the end of October 2015. We again find that the relative movement in portfolio share is driven by rebalancing and not by ex ante differences in portfolios and differences in post-election performance. Appendix Figures A.11a and A.11b show the same plots for excess bond and cash trades (defined analogously).

While these results present the data in a transparent manner, they do not show that changes in beliefs are the driving force for these re-allocations rather than differences in preferences or differential changes in hedging needs due to differential changes in the stochastic process of labor income or the local local economy. Much existing research relates reported beliefs to economic behaviors (see Manski, 2018) and to portfolio choice in particular (e.g. Vissing-Jørgensen, 2003; Ameriks et al., 2020; Giglio et al., forthcoming). In general, however, many factors change both behavior and beliefs, and so may contaminate any analysis of the effect of beliefs on behavior. Because we have identified a particular source of variation in beliefs, we can address the main ways in which the election may have directly impacted behavior other than through beliefs. For example, the election outcome raised the probability of reductions in personal and corporate tax rates, changes in personal tax deductions through itemization, increases in barriers to trade, and reductions in various regulations, and the stock prices of companies in different industries were impacted quite differently. To the extent that affiliates of one party or the other are impacted differently by these policies, or tend to work for or live near winning industries, then the political outcome may differentially affect their future incomes and cost of living. The next section provides evidence that the differences in rebalancing are not driven by the different economic effects of the election but rather by different interpretations of the election. These results thus lend credence to the informativeness of reported expectations data. 


\section{Quantitative Analysis Controlling for Alternative Channels}

To control for differences in economic outcomes and hedging needs due to the election result and to quantify the differences in portfolio allocations across households, we now run a set of regressions of changes in household equity shares on the Republican share of donations at the zip code level. We continue to study portfolio changes between one year before the election and one year after the election.

\section{V.A Quarterly Panel Regressions}

We start our quantitative analysis by running quarterly panel regressions. We use portfolios exactly one year before the election to construct initial positions and create a sample of portfolio holdings every three months, starting with the end of January 2016 and ending with the end of October 2017, so we have four observations before the election (denoted $-3,-2,-1$, and 0 for October 31, 2016) and four periods after the election $(1,2,3$, and 4).

We estimate an equation of the form:

$$
P_{i, t}=\sum_{s \neq 0}\left(\beta_{s} R_{z(i)}+\theta_{s}^{\prime} X_{i}\right) \mathbb{1}_{t=s}+\tau_{t}+\tau_{i}+\eta_{i, t}
$$

where $P_{i, t}$ is household $i$ 's portfolio share in equity at time $t, R_{z(i)}$ is the time-invariant Republican share of donations in zip code $z(i), X_{i}$ are individual control variables, $\mathbb{1}_{t=s}$ is an indicator variable which takes the value 1 when period $t=s$, and $\tau_{t}$ and $\tau_{i}$ are period-specific and individual-specific intercepts, respectively. Standard errors are clustered at the zip code level.

Our main effects of interest are the coefficients on Republican share in each three-month period following the election ( $\beta_{t}$ for $t=1,2,3,4$ ) which measure the differential effect of Republican share relative to October 31 (because we impose $\beta_{0}=0$ ).

It is important to emphasize that the effects of our control variables are allowed to be different in every three-month period, just like the effect of the Republican share. Thus, when we control for a variable, we are not controlling for its average effect pre-election and post-election, but we are controlling for differences related to this control variable in the specific quarter. ${ }^{29}$

To show that the differences in portfolios that we observe are due to differences in beliefs rather than differential economic outcomes or hedging demands, we make use of many control variables, $X_{i}$, related to differences in preferences, incomes, other wealth, or the ways these factors are exposed to economic policies. Our baseline control variables include the initial portfolio equity share, age, gender, marital status, log initial wealth, and log labor income in 2015, which are as noted all interacted with quarterly indicator variables. Initial equity shares and financial wealth are mea-

\footnotetext{
${ }^{29}$ We force $\theta_{0}=0$ to avoid collinearity with the individual effects.
} 
sured as of October 2015. These controls are designed to confirm that our quantitative results are not biased by initial differences in wealth and portfolios that might be due to heterogeneity in, for example, risk aversion, as investors that differ ex ante in endowments or risk preferences select different portfolios and are therefore differentially affected by the election outcome. Portfolio allocations are also significantly mean reverting, which is most obvious at the extremes of the distribution of initial portfolio shares, since shares are bounded by zero and one, but happens across the whole distribution. We additionally control for ex-ante differences in sectoral allocations (as discussed at the end of Section III) and for zip code house price growth between 2010 and 2015 in the baseline. We use the all-homes Zillow Home Value Index (ZHVI) as a measure of house prices at the zip code level.

Panel (a) of Figure 9 shows the cumulative change, from the end of October 2016, in the equity share of Republican zip codes relative to Democratic zip codes from this baseline regression. During the first three months following the election, people in a zip code with only Republican donations increase their holdings of equity by 0.40 percent of their portfolio relative to a zip code with only Democratic donations, rising to 0.62 percent by the end of the second three-month period following the election. The cumulative effect further increases slightly between six and twelve months after the election.

Since equity shares also reflect changes in asset valuations and do not only reflect active decisions by the account owners, we also report the results of the same baseline regression but now using the hypothetical price-constant equity share measure from Section IV as outcome variable. This measure is purely driven by active rebalancing decisions. Panel (b) of Figure 9 reports similar effects for this measure. We will use the transactions-based price-constant equity share measure as our main outcome variable in later tests.

Finally, we control for any possible channels through which the election outcome and the dynamics of future policy might impact investors differentially through their employer or locality and so change their portfolio behavior other than through beliefs. We replace all the county-level and employer-level control variables with a fixed effect for each employer-county pair. This version of equation (2) then compares, in each quarter, investors working at the same firm and living in the same county while still controlling for the effect of all the individual-level characteristics in that quarter (and an individual effect across quarters). Panel (c) of Figure 9 show the effects of the election outcome on investors equity shares controlling for these employer-county-period fixed effects. These quarterly panel regressions show the same effect of the election on portfolios: Democrat's reduce their holdings of equity while Republicans inscrease theirs. Panel (d) of Figure 9 shows that these results are due to differences in active trading not differences in passive appreciation. $^{30}$

\footnotetext{
${ }^{30}$ Appendix Tables A.2 and A.3 report the estimated coefficients in these panel regressions of equity shares and price-
} 


\section{V.B Annual Portfolio Changes}

Having reported the main quantitative estimates in quarterly panel regressions with individual fixed effects, we now switch to regressions in annual first differences for our subsequent analyses. These regressions show the same patterns in portfolio allocation changes at a yearly frequency, but are more tractable for exposition and computation. In particular, we estimate an equation of the form

$$
\Delta P_{i, t}=\beta_{0} R_{z(i)}+\beta_{1} R_{z(i)} \text { Post }_{t}+\theta_{0}^{\prime} X_{i, t-1}+\theta_{1}^{\prime} X_{i, t-1} \text { Post }_{t}+\tau_{t}+\eta_{i, t}
$$

where $t=0$ is the period October 31, 2015 to October 31, 2016, and $t=1$ is the subsequent 12 months, where $\Delta P_{i, t} \equiv P_{i, t}-P_{i, t-1}$, and where Post $t_{t}$ is an indicator variable that takes the value 1 in period $t=1$. The controls $X_{i, t-1}$ include the lagged equity share and other covariates that are either time-invariant or measured at $t-1$.

Table 3 reports estimates of equation (3) for changes in the equity share of price-constant portfolios (the corresponding findings for realized equity shares are in Appendix Table A.4). For consistency, we restrict the regression sample to RIs for which we observe a complete set of controls, so that sample sizes do not change across columns. This subsample of households with complete controls forms $27.7 \%$ of the full RI sample. In Appendix A.3.1, we show that our findings are not driven by this sample selection and that the results extend to less restrictive samples.

The first column of Table 3 reports estimates for the specification without any controls $X_{i, t-1}$. As before, we find that likely Republican households significantly increase their equity holdings relative to likely Democratic households after the election shock. In the remaining columns, we show that the main effect remains very similar as we control for a large number of variables that measure possible differences in wealth or hedging needs that might be correlated with the political affiliation of zip code of residence.

The second column shows the results for the baseline set of controls. We report the main coefficients on political affiliations, as well as the coefficients on the most important controls. In the year prior to the election, likely Republicans mildly reduce their equity share relative to likely Democrats. After the election, likely Republicans significantly increase their equity share relative to likely Democrats. The total post-election difference is 0.8 , matching the previous cumulative

effect from quarterly panel regression with individual fixed effects as reported in panel (b) of Figure 9.

To control for ex-post differences in wealth growth, the third column includes ex-post realized income growth from 2016 to 2017 and house price growth between 2015 and 2017. Columns (4) and (5) control for any remaining differences in hedging needs due to employment opportunities. constant equity shares, respectively, for the various sets of controls. 
Column (4) includes an indicator variable for employer industry (3-digit NAICS). ${ }^{31}$ Column (5) takes this control one step further by including indicators for each employer in each year. By controlling for employer effects, we absorb any differences across households that are due to Republicans and Democrats working for different firms and therefore are differentially affected by the election outcome in their expected labor income or due to differences in retirement investment menus.

Columns (6) and (7) show that we still find that Republicans increase their relative equity share when we control for detailed locational indicators. These indicators capture differences in local economic conditions and the local effects of various economic policies that lead to ex-post heterogeneity in the effects of the election outcome on wealth and hedging needs. Specifically, we control for regional variation with indicators for state and county. These indicators account for potential differences in hedging needs related to the real effects of trade or immigration policies, by absorbing differences in urbanicity, manufacturing shares, and firms' exposure to import competition (Feenstra, 1996; Barrot et al., 2019). It is worth emphasizing again that, as in the previous columns, all controls are interacted by annual indicators. The locational controls do not do much to decrease the magnitude of our main finding.

Ultimately in column (8), we control for the main ways in which rational hedging demand might change differentially in response to the election through the investor's employer or through their local economy. We still find the same differential trading behavior when we control for employer-county-period fixed effects by including an indicator for each county interacted with each employer interacted with each annual period. This specification compares people in the same year working for the same employer and living in the same county but living in zip codes with different party affiliations. The magnitudes of our main effects are highly significant although somewhat reduced in magnitude, but this may occur because these indicator variables may be absorbing some valid variation, since our main measure of the effect of beliefs is a noisy measure of party affiliation at the zip code level.

The results in this last column of Table 3 have interesting implications for the interpretation of our findings related to work on differences in media and political beliefs, as discussed in the introduction. By controlling for county, we are largely controlling for access to information since people in the same county likely have access to the same media for example. Thus, to the extent that the variation in beliefs across zip codes within a county is related to differences in the consumption of media, then, these differences in media represent differences in the demand for certain types of information. That is, we are not measuring the effect of exogenous differences in media consumption, but the expression of individual (or rather zip code level) beliefs. ${ }^{32}$

\footnotetext{
${ }^{31}$ The results are similar for 2-digit and for 4-digit NAICS controls.

${ }^{32}$ Although beliefs may be amplified or perpetuated by choice of media, they still represent choices driven by initial political identity. Note however that our controls for supply are incomplete in the sense that new media platforms (e.g.
} 
Our main results are quite similar for our alternative measures of likely political affiliation in 2016 and for the 2012 Republican vote share by county (see Appendix Table A.5). Thus, our results are not driven by something specific to donations (rather than votes) or by something particular to the candidates in 2016 (although we do not have a way to adjust for differences in turnout). At the one-year horizon with employer-state-period fixed effects, we find no statistically significant evidence that changes over time in the intensity of county support matter above and beyond the 2012 vote shares. $^{33}$

In sum, the regression analysis of this section confirms that the public signal of the 2016 election caused likely Republicans to increase their portfolio exposure to US growth relative to likely Democrats, and that we find this behavior even when controlling for many measures of differences in the real economic impact of the election, such as only using variation within people living in the same county and working for the same employer. These results are consistent with survey beliefs reported in Section II: households that are more optimistic on the future growth of the US economy increase their exposure to assets that load on future economic performance. ${ }^{34}$

The relative changes in portfolios that we find are not quantitatively large. In part this is because we do not observe individual-level political affiliations, so that even quite Republican or Democratic zip codes by our measures contain a mixture of Democratic and Republican investors. However, in part our effects are not large because most of the wealth of retirement investors is retirement wealth, and there is very little (active) trading in retirement accounts. As prior research has shown, retirement savers in the US largely stick to their default portfolio allocations and trade very rarely.

Due to infrequent rebalancing, the magnitudes of the coefficients of portfolio changes are modest on all explanatory variables. However, Table 3 shows that compared with key investor characteristics such as age, wealth, income, gender, and marital status, we find that the coefficient on

Twitter, Facebook, etc.) target at the individual level with little relation to geography. See the related work of Gentzkow and Shapiro (2006), Mullainathan and Shleifer (2005), and Martin and Yurukoglu (2017).

${ }^{33}$ Not only can we use the 2012 vote share in our analysis of the 2016 election, but we can also conduct our same analysis using rebalancing around the 2012 election. We perform an identical regression analysis on a data sample from our proprietary data using our same procedure but just changing the dates to cover the year before and after the 2012 election. Appendix Figure A.12 shows the changes in equity shares around this election. The first few columns of Appendix Table A.6, with plain equity shares and few controls, show Democrats increasing their equity shares relative to Republicans following the 2012 election, opposite to the rebalancing that we find in 2016. However, the later columns with more controls largely eliminate this effect, and we also find null results for price-constant equity shares in Appendix Table A.7. Thus, with additional controls there is no differential effect of party affiliation on rebalancing following the 2012 election. We conclude that there is not a general tendency for Republicans to increase their equity shares following elections or when the market does well (as it did after the 2012 election), and that Democrats may have become (relatively) more optimistic and (relatively) rebalanced into equity, but, consistent with the unsurprising nature of the outcome of the 2012 election, this evidence is limited and only appears in some specifications.

${ }^{34}$ Consistent with the survey evidence on beliefs as well as with theoretical models of belief heterogeneity, we interpret our findings on portfolio allocations as the result of disagreement on expected stock market returns. It is however also possible that the results (partially) reflect heterogeneity in beliefs on higher-order moments such as expected volatility or tail risk in asset returns. 
likely political affiliation is large. For example, in column (8) of Table 3, the magnitude of the post-election difference between likely Republicans and likely Democrats is equivalent to an age difference of 36 years, a difference in wealth of 377 log points, and a difference in income of 445 $\log$ points in the election response. Zip-code-level regressions in Table A.11 (further described in Appendix A.3.2) also show that apart from initial equity shares, zip code political affiliations are the most important variable for explaining post-election changes in portfolio allocations across zip codes. However, most of the variation in portfolio changes is due to idiosyncratic factors, especially at the individual level - the overall $R^{2}$ in Table 3 is $6.7 \%$ without fixed effects and $18.9 \%$ with employer by county fixed effects.

In the next section, we show that our estimated main effect is much larger among households that do reallocate their wealth.

\section{Inaction and Large Portfolio Changes}

Having established our main results, we now show that the portfolio reallocation is due to a small share of active investors who make large reallocations in their portfolios.

First, we focus on the effect among active investors. Table 4 performs the same analyses as Table 3 on the subset of the population with an active portfolio reallocation during the year prior to the pre-election year. An active portfolio reallocation is defined as an equity share change of at least $5 \%$ caused by trading in a particular month. As in our graphical analysis, we find much larger differential portfolio movements among active households. The relative increase in equity share among likely Republicans who have made active reallocations is three times as large as that for the general population of RIs.

We also analyze several other categorizations of more active or engaged investors, such as those invested less in target date funds and those with greater past access and trading behavior in their accounts. We relegate these results to Appendix Table A.8, but we find that the more active the investors are that we include in the sample, the greater are the differences in reallocation. Notably, relative reallocations are much greater - five times the baseline effect - among investors who made active reallocations in each of the three years prior to the election (1.7 percent of RIs). Investors who are less engaged, for example those who have a significant part of their assets in target date funds or advised accounts, respond less than the average investor. ${ }^{35}$

We next turn to measuring the size of the portfolio adjustments made by the investors that actively rebalance. As in our previous analysis, we continue to focus on hypothetical portfolios

\footnotetext{
${ }^{35}$ Instead of classifying investors by their engagement ex ante, we can also look at portfolio reallocation conditional on active rebalancing ex post. Appendix Table A.9 shows the results of regressing annual portfolio changes on political affiliation and various controls for the sample of investors that actively reallocate their portfolios in that particular year. Not surprisingly, we find even larger effects.
} 
constructed as if there were no changes in valuations of funds or securities. This allows us to cleanly avoid changes in equity share driven by different returns on different investments. Figures 10a and 10b show the changes in equity shares as in Figure 8a, decomposed into small and large portfolio changes. In the upper panel we take the average of (hypothetical) equity share changes relative to October 2016 interacted by an indicator for the change being at least ten percent. In the lower panel we multiply the (hypothetical) equity share change by an indicator for the change being at most ten percent. There is no noticeable differential active adjustment among the investors making only small adjustments and effectively our entire measured effect comes from investors making adjustments of greater than ten percent. In terms of what share of investors are making these large trades, roughly one percent of investors make a trade of greater than 10 percent in each month following the election.

To further characterize the extent to which our results are driven by large reallocations, we rerun our main analysis on the subsample of investors whose cumulative adjustment over the year following the election exceeds $X$ percent, for different values of $X$. Strikingly, only about a quarter of the total relative portfolio reallocation comes from investors who adjust the equity shares of their portfolios by less than $25 \%$. A full half the measured effect comes from the few households that increase or decrease the equity share of their portfolio by $50 \%$ or more. We display the complete set of results in Appendix Figure A.13a.

What share of investors are making these large changes? Aggregated across the full year, $9.6 \%$ of our RI sample reallocate so that their equity share changes by at least $10 \%, 4.3 \%$ reallocate for a change of at least $25 \%$, and $1.7 \%$ make a change of at least $50 \%$.

We further find that rebalancing at the individual level is lumpy. Investors tend to make only one large trade. Examining the cumulative difference in reallocation between the most Republican zip codes and the most Democratic zip codes, we experiment with dropping all adjustments made by investors after their first rebalancing of ten percent or greater. Almost the entire effect comes from the first large adjustment made by each investor (as shown in Appendix Figure A.13b). In sum, effectively no Republican and Democratic investors actively change their equity shares by only a few percent in response to the election. Instead, a small share of investors make very large changes in their portfolios in response to their different changes in their beliefs.

These results are consistent with previous studies which show that the typical American investor, whose wealth is primarily in retirement funds, trades very rarely (e.g. Choi et al., 2004). The interesting question is: why? The majority of wealth in our sample is retirement wealth, which has no fees associated with trading. Thus large monetary costs are an implausible explanation. Instead, inaction seems to be due to psychological or informational costs. This interpretation is supported by our finding that investors who are more engaged with their portfolio allocations respond more strongly, and those who have delegated or are less engaged respond less. While it is 
possible that only a few households updated their beliefs following the election, this interpretation is inconsistent with the evidence from survey beliefs in Section II.

\section{Trading Volume}

A main motivation and implication of models with time-varying heterogeneous beliefs is that they generate trade among agents, something that the canonical model is either silent about or, when calibrated, tends to vastly under-predict. In this section we show that trading volume rises significantly following the election for our RI sample, consistent with these models and our interpretation of the election as a public shock that caused different movements in different households' beliefs.

We measure trades as the absolute value of the dollar amount of every purchase or sale of any security $s$, and define the trading volume for household $i$ in month $t$ as: ${ }^{36}$

$$
\text { Trading } \text { Volume }_{i, t}=\frac{\frac{1}{2} \sum_{s}\left(\left|\mathrm{Buy}_{i, s, t}\right|+\left|\operatorname{Sell}_{i, s, t}\right|\right)}{\text { Assets }_{i, 0}},
$$

where Buy $_{i, s, t}$ is the sum of all buying transactions for household $i$ in month $t$ of security $s$, Sell $i_{i, s, t}$ is the sum of all selling transactions for that security by the household in that month, and the total amount of trading is scaled by initial household assets Assets $_{i, 0}$. Since this trading includes purchases and sales from inflows and outflows, we also construct a measure of active trades, which are trades limited to rebalancing across assets, excluding those associated with inflows and outflows.

Figure 11a plots average trading volume over time and shows that the volume of trade by our sample of retirement investors the amount of trade rises significantly following the election. Their average trading volume is low (relative to turnover in the overall stock market), roughly $2.25 \%$ per month prior to the election. Active trades are roughly $1 \%$ per month. Trading increases significantly in the month following the election, reaching more than 3\% per month in March 2017. Figure 11b shows that there is little difference in trading volume across the distribution of political affiliation in zip codes, including those that are most politically balanced. This similarity suggests that the Republicans and Democrats in non-homogeneous zip codes are both trading, just in opposite directions.

In contrast, there is no noticeable increase in trading activity in US equity markets overall, even in the submarket for ETFs. Presumably, this is because the trading of our sample is such a small share of total trade in US equity markets. We confirm this both with total US equity market volume and with the narrower ETF market volume, both from the CBOE (we plot these series in Appendix Figures A.14a and A.14b).

\footnotetext{
${ }^{36}$ Trading volume is winsorized at $100 \%$ to remove sensitivity to a small number of extreme outliers. This affects less than $0.5 \%$ of the sample.
} 
We conclude that the evidence on trading volume supports our hypothesis that this public event was interpreted differently by people with different models of the world, but we also note that this particular source of different beliefs can generate only a small amount of observed equity trades.

\section{Differences across Households and Accounts}

Which characteristics of investors are associated with the largest differential responses to the election news? We characterize differences in the effect of the election by running triple difference regressions to measure differential effects by prior-year active rebalancing, age, wealth, and starting equity share. We report the coefficients on the Republican contribution share and its interactions in Table 5, where age, log wealth, and lagged equity share are all demeaned.

The interaction of Republican contribution share with active reallocation in the prior year in column (2) highlights and confirms our previous results. The response in the equity shares of households with active rebalancing in the prior year is almost four times as strong as those who were not active. Turning to age in column (3), older households - those closer to retirement but also with more wealth and income - have more differences in their portfolios by political affiliation than younger households. Relative to a base difference of 0.87 percent, a ten year higher age is associated with an additional difference in equity share changes of 0.51 percent between likely Republicans and likely Democrats. Column (4) shows that equity share moves relatively more for wealthier households, with a doubling of financial wealth implying a 0.25 percent greater relative increase in equity shares by likely Republicans, and a doubling of income implying a 0.43 percent greater relative increase in equity shares. The difference in reallocation is larger for investors with relatively low starting equity shares, as shown in column (5). With the full set of demographic interactions in column (6), age becomes less important, while heterogeneity by financial wealth, income, and initial equity allocation remains highly significant.

Next, do households rebalance differently depending on the type of account they own, or do we see differences across households that own different types of accounts? We find that there are significant responses across all types of accounts, with larger responses for people with nonretirement accounts but more rebalancing in retirement accounts. Table 6 shows how the responses differ across investors or different types of accounts held by RIs at the firm. The first column presents our main results again, which largely represent the response in retirement accounts since this is the vast majority of wealth held by our RIs. In the second column, we restrict the sample to households that own personally advised accounts. ${ }^{37}$ Both pre- and post-election coefficients on political affiliation are somewhat larger, but with very large standard errors when we insist on

\footnotetext{
${ }^{37} \mathrm{~A}$ common financial adviser line is "keep your politics out of your portfolio."
} 
including employer-county-year fixed effects. The third column shows a slightly lower but still highly significant estimate for the subset of households with a single, unmarried household head. Because we may only observe one member of a household, we are more confident that we observe the full portfolio of unmarried investors. A possible explanation for the lower magnitude in this

sample is that these are typically younger investors with lower balances and a higher initial equity allocation.

In the final five columns, we draw a distinction between retirement and non-retirement account behavior and owners. Given the prominence of retirement wealth in our sample, we find similar results when we restrict attention to only retirement wealth (column (4)). We find that investors that own non-retirement accounts (column (5)) tend to trade more than people without (column (6)) and therefore show bigger responses, but for these investors we find less reallocation in their non-retirement accounts (column (7)) than in their retirement accounts (column (8)), presumably for reasons of both lower transaction costs and no immediate tax ramifications (see Dammon et al., 2001). Hence, we find no evidence that reallocation happens more in non-retirement accounts that may offer more flexibility in choosing asset allocations or have shorter investment horizons.

\section{Extensions}

\section{IX.A Household Saving Behavior}

Gerber and Huber $(2009,2010)$ began a literature in political science studying whether local economic activity is affected differently by elections in localities with different political affiliations. These papers and the subsequent literature has primarily focused on consumption spending (McGrath, 2017; Benhabib and Spiegel, 2019; Gillitzer and Prasad, 2018; Mian et al., forthcoming). While there is disagreement across the papers, the balance of this evidence suggests little to no differential effect of the election on local consumption levels across areas with different dominant political affiliations. This finding is striking in part because one would expect differential real effects of the election outcome through policy on the current, and future economic circumstances of people with different political affiliations. In contrast to this literature, we measure individuallevel behavior controlling for the real effects on the local economy and labor income.

In this section, we investigate saving using three measures of inflows into accounts. We show that there is some weak evidence that the typical Republican retirement investor increased their savings in investment accounts by a small amount following the election, relative to their Democratic counterparts.

First, we investigate a measure that exists for all RIs in our sample, the net flow rate, defined 
as net account inflows less account outflows as a share of total initial balance:

$$
\text { Net Flow Rate } \text { Rit }=\frac{\text { Deposits }_{i, t}-\text { Withdrawals }_{i, t}}{\text { Financial Wealth }_{i, 0}} .
$$

Figure 12 shows the average of this saving rate by zip code bin at a monthly frequency and reveals no noticeable differences by likely party affiliation. We also run a regression similar to that in Section $\mathrm{V}$, but using the year-on-year change in annual net flow rate as the dependent variable. Columns (1) and (2) of Table 7 show that Republican households, who become more optimistic, increase their saving rate relative to Democratic households following the election. Including employer-county-period fixed effects has a big impact on the estimates - the pre-election trend disappears and the overall effects are smaller.

Second, at some loss of sample size, we can instead measure a saving rate more directly by defining the net saving rate as net inflows divided by income:

$$
\text { Net Saving Rate } \text { Re }_{i, t}=\frac{\text { Deposits }_{i, t}-\text { Withdrawals }_{i, t}}{\text { Income }_{i, t}} .
$$

This has the obvious advantage of being a more standard measure of the saving rate but limits our sample to RIs for which we observe annual income for the head of the household. Columns (3) and (4) of Table 7 again show evidence that Republican households save more relative to Democratic households following the election, with no pre-election differences once we control for employer by county by year fixed effects. The effect on political affiliation is economically small but not trivial, on the order of three quarters of a percent of income. Columns (5) and (6) of Table 7 show similar results when we limit financial flows to accounts owned by the head of the household for whom income is measured.

A disadvantage of these first two measures of saving rates is that they have a lot of variation over time and across people because of large withdrawals and large inflows, presumably both significantly due to transfers out of and into the financial institution rather than due to actual saving. To address this issue, we measure the retirement saving rate as the contribution rate (as a percentage of income) chosen by the head of the household in his or her active retirement account. The advantage of this measure is that it avoids account inflows and outflows that represent transfers from and to other institutions. This measure still does not avoid the possibility of substitution between retirement saving and non-retirement. Columns (7) and (8) of Table 7 show that in the year prior to the election, the contribution rates of Democratic investors rose faster. Most of this difference can be explained by employer effects. There is no statistically significant difference in contribution rate changes post election by party affiliation. The effects are also economically small, on the order of 0.05 percent of income. 
We take this evidence as suggestive of only very small effects of the election on households' saving rates. If this were also true of consumption spending, this would have two implications. First, and less important given our extensive controls, a non-response of consumption further mitigates the concern that differences in the economic effects of the policy changes cause the differences in portfolio responses that we find. Second, only certain utility functions are consistent with differences in beliefs that cause differences in portfolio exposures to risk without causing differences in consumption changes. Specifically, these findings are consistent with a unit elasticity of intertemporal substitution.

The Michigan SCC data also supports this interpretation. As we showed in Figures 2a and 2b, in contrast to the large changes in beliefs about the future of the US economy, households report only small changes in their expectations about their own personal economic situations. Here we show some evidence that Republicans and Democrats do not report changing their views about whether it is a good time to consume.

Also consistent with this finding, the SCC shows only small differential changes in responses to the questions: "Generally speaking, do you think now is a good or a bad time for people to buy major household items / a house?" (see Appendix Figures A.15a and A.15b). Consistent with the strong economy, most people believe it is a good time to buy a house or major durable item before the election, with Democrats being slightly more optimistic than Republicans only for the purchase of a durable item. This difference goes away after the election, with beliefs about the purchase of a durable item similar by party affiliation. For the purchase of a house, Republicans and Democrats hold similar views prior to the election and Republicans become slightly more optimistic following the election.

\section{IX.B Differences in the Composition of Equity Holdings}

The quantitative analysis so far has concentrated on the equity share as a summary measure of investor portfolios. Figure $8 \mathrm{~b}$ shows that the market beta of price-constant portfolios of Republicans also rises relative to Democrats after the election. Consistent with these raw effects, columns (1)(3) of Table 8 find that likely Republicans increase the market beta of their portfolios relative to likely Democrats in the post-election year under the full set of controls. Next, we turn to a more detailed decomposition of investor portfolios. We find that differential portfolio reallocation after the election is concentrated on rebalancing across asset classes.

First, to what extent are differences in the portfolio market beta of people with different political affiliations due to differences in the market beta of the equity portfolio? Figure 13a shows both minimal differences in the market beta of equity by party affiliation and only small relative changes in the beta of equity following the election. Columns (4)-(6) of Table 8 quantify these differences. Within equity we do not see an increase in the market exposure of Republicans relative 
to Democrats, controlling for ex-ante differences. This finding is consistent with our focus on the rise in the equity share of Republicans relative to Democrats in our main set of results.

Second, do we see differences in the post-election reallocation across sectors? Stock market performance differs substantially across stocks and sectors expected to benefit from the unexpected change in party control (Wagner et al., 2018). We have seen that there are differences in the exante composition of household equity holdings; controlling for this heterogeneity does not alter our main results. In addition, we find no evidence of hetereneous reallocation after the election. Columns (7)-(10) of Table 8 show insignificant coefficients for changes in the winning and losing sectors share of equity on the Republican contribution share. These results suggests that investors of different political affiliations do not disagree on the extent to which the election differentially impact the different sectors of the economy, and are inconsistent with alternative explanations of our main finding that equity share changes differ by party affiliation through differences in information or tastes. If Republicans are better able to identify firms or sectors that do well after the election or have more taste for holding those types of assets, we should observe significant differential changes in the composition of equity portfolios following the election. We do not observe such changes (see also the plots in Appendix Figure A.16.)

Third, do differences in beliefs about the future state of the US economy translate into differential shifts into and out of international equity investments? We find no evidence of differential changes in international equity allocations. ${ }^{38}$ Figure $13 \mathrm{~b}$ shows the share of international equity across households sorted into quintiles by party affiliation of their zip code, relative to the end of October 2016. Prior to the election there is a small relative decrease in the international share held by the most Democratic zip codes and there is a similar small relative decrease following the election. Columns (11) and (12) of Table 8 show that in the regression analysis with full controls, there are no significant differential changes in the international equity share of Republican areas relative to Democratic areas.

\section{IX.C The Impact of Different Changes in Beliefs on Asset Demand}

The public signal of the election changed beliefs and caused trade and portfolio allocation across households. Did this change in disagreement change the net demand for equity of the retirement investor sample that we observe? Did the heterogeneous changes in beliefs and the resulting trade contribute to the high returns on the stock market following the election?

We can provide only a very rough answer to these questions. We begin by defining the baseline relative to which we measure the effect of differences in the updating of beliefs. We assume that there would have been no change in the demand for equity from the election had the Democratic

\footnotetext{
${ }^{38}$ Individual equity is classified as international if it is traded on an international exchange or if the company is incorporated outside the US. Equity funds are classified as domestic or international based on their product description.
} 
candidate won the election, that is, had the much more likely outcome occurred. Further, we base our calculation on our regressions using county vote share as the measure of political affiliation (see Appendix Table A.5) and assume there was no net change in the demand for equity in a county in which investable wealth is evenly split between Democrats and Republicans. Finally, we assume that wealth is uncorrelated with party affiliation within counties.

Under these three significant assumptions, the change in net demand for equity from each county is our regression coefficient times county wealth times the difference between county vote share and 0.5. Summing across counties leads to a decrease of $\$ 660$ million in the demand for equity by the investors that we observe over the year following the election.

What about the aggregate demand for equity? We only observe a fraction of the retirement investors and wealth in each county. To scale our estimate to a measure for all retirement investors, we scale up the demand in each county by multiplying by the share of the population that we observe in that county (based on US Census data) times the national share of households that are retirement investors (from the 2016 SCF). Again, summing across counties, this crude estimate implies that the demand for equity declined by $\$ 1.09$ billion among retirement investors in the US. Finally, while we do not know much about the political affiliations of very wealthy households, if we simply scale this number up by the inverse of the share of the investable wealth in the US held by retirement investors in the 2016 SCF, this back-of-the-envelope calculation implies that the election causes a decrease in the net demand for equity of $\$ 4.37$ billion in the year following the election. This is obviously a very rough estimate, but far too small a number to have had a noticeable effect on returns during the year following the election.

\section{Concluding Discussion}

We study the unexpected outcome of the 2016 US election as a public signal that is widely-observed, well-measured, and for which we have ex ante measures of how different investors should interpret this signal given their identities, or models that they use to interpret the world. We find that people with different political affiliations update their beliefs and rebalance their portfolios differentially in response to a common public signal. A correlation between differences in beliefs and differences in behavior may not be causal, and an important contribution of our analysis comes from our controls for an extensive array of other factors that affect rebalancing differentially such as through the real effects of changes in economic policies on incomes or local risk exposures. Consistent with dynamic models of heterogeneous beliefs, we show that the heterogeneity in updating across households leads to an increase in trading volume.

Reported beliefs data also suggest that Democrats indeed became more pessimistic about the US economy following the election and that Republicans became more optimistic. In contrast, peo- 
ple do not report the same polarized expectations about their own personal situations. Relatedly, our retirement savings data also do not show differences in saving rates across households with different affiliations.

Finally, while we find small average differences in rebalancing between Democrats and Republicans following the election, these small averages are driven by very large rebalancing by a small share of investors. Across both investors and accounts, the trading responses we find are consistent with the inertia generally found for typical American retirement investors. We also find that differences in rebalancing persist over many months after the election, which is consistent with investors being aware that there is disagreement and that prices do not rapidly incorporate their own views. 


\section{References}

Akerlof, George A. and Rachel E. Kranton, "Economics and Identity," The Quarterly Journal of Economics, 2000, 115 (3), 715-753.

Alesina, Alberto, Stefanie Stantcheva, and Edoardo Teso, “Intergenerational Mobility and Preferences for Redistribution," American Economic Review, 2018, 108 (2), 521-54.

Ameriks, John, Gábor Kézdi, Minjoon Lee, and Matthew D. Shapiro, "Heterogeneity in Expectations, Risk Tolerance, and Household Stock Shares: The Attenuation Puzzle," Journal of Business \& Economic Statistics, 2020, 38 (3), 633-646.

Autor, David, David Dorn, Gordon Hanson, and Kaveh Majlesi, “Importing Political Polarization? The Electoral Consequences of Rising Trade Exposure," American Economic Review, 2020, 110 (10), 3139-83.

Bailey, Michael, Ruiqing Cao, Theresa Kuchler, and Johannes Stroebel, "The Economic Effects of Social Networks: Evidence From the Housing Market," Journal of Political Economy, 2018, 126 (6), 2224-2276.

Bamber, Linda Smith, Orie E. Barron, and Thomas L. Stober, “Differential Interpretations and Trading Volume," Journal of Financial and Quantitative Analysis, 1999, 34 (3), 369-386.

Banerjee, Snehal and Ilan Kremer, "Disagreement and Learning: Dynamic Patterns of Trade," Journal of Finance, 2010, 65 (4), 1269-1302.

Barber, Brad M. and Terrance Odean, "All That Glitters: The Effect of Attention and News on the Buying Behavior of Individual and Institutional Investors," Review of Financial Studies, 2008, $21(2), 785-818$.

Barrot, Jean-Noël, Erik Loualiche, and Julien Sauvagnat, “The Globalization Risk Premium,” Journal of Finance, 2019, 74 (5), 2391-2439.

Bartels, Larry M., "Beyond the Running Tally: Partisan Bias in Political Perceptions," Political Behavior, 2002, 24 (2), 117-150.

Bénabou, Roland and Jean Tirole, "Identity, Morals, and Taboos: Beliefs as Assets," The Quarterly Journal of Economics, 2011, 126 (2), 805-855.

Benhabib, Jess and Mark M. Spiegel, "Sentiments and Economic Activity: Evidence from US States," The Economic Journal, 2019, 129 (618), 715-733. 
Bonaparte, Yosef, Alok Kumar, and Jeremy K. Page, "Political Climate, Optimism, and Investment Decisions," Journal of Financial Markets, 2017, 34, 69-94.

Brunnermeier, Markus, Emmanuel Farhi, Ralph S J Koijen, Arvind Krishnamurthy, Sydney C Ludvigson, Hanno Lustig, Stefan Nagel, and Monika Piazzesi, "Review Article: Perspectives on the Future of Asset Pricing," The Review of Financial Studies, April 2021, 34 (4), 2126—-2160.

Brunnermeier, Markus K. and Jonathan A. Parker, "Optimal Expectations," American Economic Review, 2005, 95 (4), 1092-1118.

Bullock, John G., Alan S. Gerber, Seth J. Hill, and Gregory A. Huber, "Partisan Bias in Factual Beliefs about Politics," Quarterly Journal of Political Science, 2015, 10 (4), 519-578.

Calvet, Laurent E., John Y. Campbell, and Paolo Sodini, "Down or Out: Assessing the Welfare Costs of Household Investment Mistakes," Journal of Political Economy, 2007, 115 (5), 707-747.

Carlin, Bruce I., Francis A. Longstaff, and Kyle Matoba, “Disagreement and Asset Prices," Journal of Financial Economics, 2014, 114 (2), 226-238.

Cheng, Ing-Haw, Sahil Raina, and Wei Xiong, "Wall Street and the Housing Bubble," American Economic Review, 2014, 104 (9), 2797-2829.

Choi, James J., David Laibson, Brigitte C. Madrian, and Andrew Metrick, "For Better or For Worse: Default Effects and 401(k) Savings Behavior," in David A. Wise, ed., Perspectives on the Economics of Aging, University of Chicago Press, 2004, pp. 81-121.

Conover, Pamela Johnston, Stanley Feldman, and Kathleen Knight, “The Personal and Political Underpinnings of Economic Forecasts," American Journal of Political Science, 1987, 31 (3), 559 583.

Cookson, J. Anthony and Marina Niessner, "Why Don't We Agree? Evidence from a Social Network of Investors," Journal of Finance, 2020, 75 (1), 173-228.

Curcuru, Stephanie, John Heaton, Deborah Lucas, and Damien Moore, "Heterogeneity and Portfolio Choice: Theory and Evidence," in "Handbook of Financial Econometrics: Tools and Techniques" 2010, pp. 337-382.

Curtin, Richard, "Economic Policy Preferences," Survey of Consumers, University of Michigan, September, http://www.sca.isr.umich.edu/files/econpoly1608.pdf 2016.

- , "Presidential Honeymoons," Survey of Consumers, University of Michigan, January, http:/ / www.sca.isr.umich.edu/files/honeym1701.pdf 2017. 
Dammon, Robert M., Chester S. Spatt, and Harold H. Zhang, “Optimal Consumption and Investment with Capital Gains Taxes," Review of Financial Studies, 2001, 14 (3), 583-616.

Das, Sreyoshi, Camelia M Kuhnen, and Stefan Nagel, "Socioeconomic Status and Macroeconomic Expectations," Review of Financial Studies, 2020, 33 (1), 395-432.

Edmans, Alex, Diego García, and Øyvind Norli, "Sports Sentiment and Stock Returns," Journal of Finance, 2007, 62 (4), 1967-1998.

Feenstra, Robert C., “U.S. Imports, 1972-1994: Data and Concordances,” NBER Working Paper No. 55151996.

Gaines, Brian J., James H. Kuklinski, Paul J. Quirk, Buddy Peyton, and Jay Verkuilen, "Same Facts, Different Interpretations: Partisan Motivation and Opinion on Iraq," Journal of Politics, 2007, 69 (4), 957-974.

Gennaioli, Nicola and Andrei Shleifer, "What Comes to Mind," The Quarterly Journal of Economics, 2010, 125 (4), 1399-1433.

Gentzkow, Matthew and Jesse M. Shapiro, “Media Bias and Reputation,” Journal of Political Economy, 2006, 114 (2), 280-316.

Gerber, Alan S. and Gregory A. Huber, "Partisanship and Economic Behavior: Do Partisan Differences in Economic Forecasts Predict Real Economic Behavior?," American Political Science Review, 2009, 103 (3), 407-426.

_ and _ , "Partisanship, Political Control, and Economic Assessments," American Journal of Political Science, 2010, 54 (1), 153-173.

Giglio, Stefano, Matteo Maggiori, Johannes Stroebel, and Stephen Utkus, "Five Facts about Beliefs and Portfolios," American Economic Review, forthcoming.

Gillitzer, Christian and Nalini Prasad, "The Effect of Consumer Sentiment on Consumption: CrossSectional Evidence From Elections," American Economic Journal: Macroeconomics, 2018, 10 (4), 234-69.

Grinblatt, Mark and Matti Keloharju, "The Investment Behavior and Performance of Various Investor Types: A Study of Finland's Unique Data Set," Journal of Financial Economics, 2000, 55 (1), 43-67.

Guiso, Luigi, Michael Haliassos, and Tullio Jappelli, Household Portfolios, MIT Press, 2002. 
Hansen, Lars Peter and Thomas J. Sargent, "Fragile Beliefs and the Price of Uncertainty," Quantitative Economics, 2010, 1 (1), 129-162.

Harris, Milton and Artur Raviv, "Differences of Opinion Make a Horse Race," Review of Financial Studies, 1993, 6 (3), 473-506.

Harrison, J. Michael and David M. Kreps, "Speculative Investor Behavior in a Stock Market with Heterogeneous Expectations," The Quarterly Journal of Economics, 1978, 92 (2), 323-336.

Hirshleifer, David and Tyler Shumway, "Good Day Sunshine: Stock Returns and the Weather," Journal of Finance, 2003, 58 (3), 1009-1032.

Hong, Harrison and Jeremy C. Stein, "Disagreement and the Stock Market," Journal of Economic Perspectives, 2007, 21 (2), 109-128.

- and Leonard Kostovetsky, "Red and blue investing: Values and finance," Journal of Financial Economics, 2012, 103 (1), 1-19.

Huberman, Gur, Tobias Konitzer, Masha Krupenkin, David Rothschild, and Shawndra Hill, "Economic Expectations, Voting, and Economic Decisions around Elections," AEA Papers and Proceedings, 2018, 108, 597-602.

Kamstra, Mark J., Lisa A. Kramer, and Maurice D. Levi, "Winter Blues: A SAD Stock Market Cycle," American Economic Review, 2003, 93 (1), 324-343.

Kandel, Eugene and Neil D. Pearson, "Differential Interpretation of Public Signals and Trade in Speculative Markets," Journal of Political Economy, 1995, 103 (4), 831-872.

Kaustia, Markku and Sami Torstila, "Stock market aversion? Political preferences and stock market participation," Journal of Financial Economics, 2011, 100 (1), 98-112.

Kempf, Elisabeth and Margarita Tsoutsoura, "Partisan Professionals: Evidence from Credit Rating Analysts," Journal of Finance, forthcoming.

Li, Dan and Geng Li, "Whose Disagreement Matters? Household Belief Dispersion and Stock Trading Volume," Review of Finance, 2021.

Linnainmaa, Juhani T., Brian Melzer, and Alessandro Previtero, “The Misguided Beliefs of Financial Advisors," Journal of Finance, 2021, 76 (2), 587-621.

Madrian, Brigitte C. and Dennis F. Shea, "The Power of Suggestion: Inertia in 401(k) Participation and Savings Behavior," The Quarterly Journal of Economics, 2001, 116 (4), 1149-1187. 
Mailath, George J. and Larry Samuelson, "Learning under Diverse World Views: Model-Based Inference," American Economic Review, 2020, 110 (5), 1464-1501.

Malmendier, Ulrike and Stefan Nagel, “Depression Babies: Do Macroeconomic Experiences Affect Risk Taking?," The Quarterly Journal of Economics, 2011, 126 (1), 373-416.

Manski, Charles F., "Survey Measurement of Probabilistic Macroeconomic Expectations: Progress and Promise," in Jonathan A. Parker and Martin S. Eichenbaum, eds., NBER Macroeconomics Annual 2017, Volume 32, 2018, pp. 411-471.

Martin, Gregory J. and Ali Yurukoglu, “Bias in Cable News: Persuasion and Polarization," American Economic Review, 2017, 107 (9), 2565-99.

McGrath, Mary C., "Economic Behavior and the Partisan Perceptual Screen," Quarterly Journal of Political Science, 2017, 11 (4), 363-83.

Merton, Robert C., "Lifetime Portfolio Selection under Uncertainty: The Continuous-Time Case," The Review of Economics and Statistics, 1969, 51 (3), 247-257.

Mian, Atif R., Amir Sufi, and Nasim Khoshkhou, "Partisan Bias, Economic Expectations, and Household Spending," The Review of Economics and Statistics, forthcoming.

Miller, Edward M., "Risk, Uncertainty, and Divergence of Opinion," Journal of Finance, 1977, 32 (4), 1151-1168.

Morris, Stephen, "Speculative Investor Behavior and Learning," The Quarterly Journal of Economics, 1996, 111 (4), 1111-1133.

Mullainathan, Sendhil and Andrei Shleifer, "The Market for News," American Economic Review, 2005, 95 (4), 1031-1053.

Pastor, Lubos and Pietro Veronesi, "Inequality Aversion, Populism, and the Backlash against Globalization," Journal of Finance, forthcoming.

Prior, Markus, "Is Partisan Bias in Perceptions of Objective Conditions Real? The Effect of an Accuracy Incentive on the Stated Beliefs of Partisans," Presented at the Annual Conference of the Midwest Political Science Association, Chicago 2007.

_ , Gaurav Sood, and Kabir Khanna, "You Cannot be Serious: The Impact of Accuracy Incentives on Partisan Bias in Reports of Economic Perceptions," Quarterly Journal of Political Science, 2015, 10 (4), 489-518. 
Scheinkman, Jose' A. and Wei Xiong, "Overconfidence and Speculative Bubbles," Journal of Political Economy, 2003, 111 (6), 1183-1220.

Simsek, Alp, “Belief Disagreements and Collateral Constraints," Econometrica, 2013, 81 (1), 1-53.

Vissing-Jørgensen, Annette, "Perspectives on Behavioral Finance: Does "Irrationality" Disappear with Wealth? Evidence from Expectations and Actions," in Mark Gertler and Kenneth Rogoff, eds., NBER Macroeconomics Annual, Volume 18, 2003, pp. 139-194.

Wagner, Alexander F., Richard J. Zeckhauser, and Alexandre Ziegler, "Unequal Rewards to Firms: Stock Market Responses to the Trump Election and the 2017 Corporate Tax Reform," AEA Papers and Proceedings, 2018, 108, 590-596. 
Figure 1: Survey Expectations on Future State of the Economy

(a) Expected Business Conditions in 5 Years

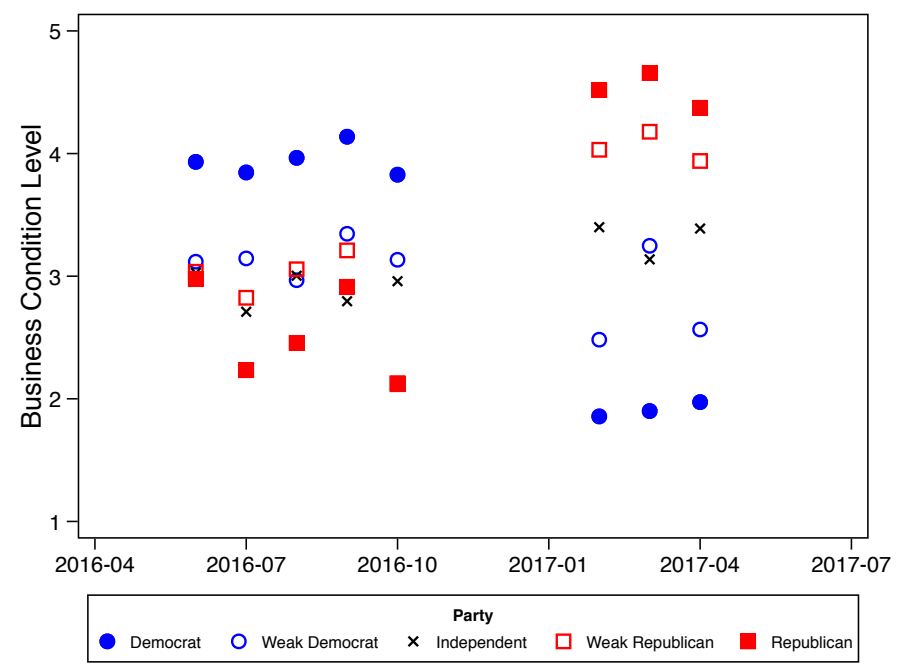

(b) Expectations on Unemployment

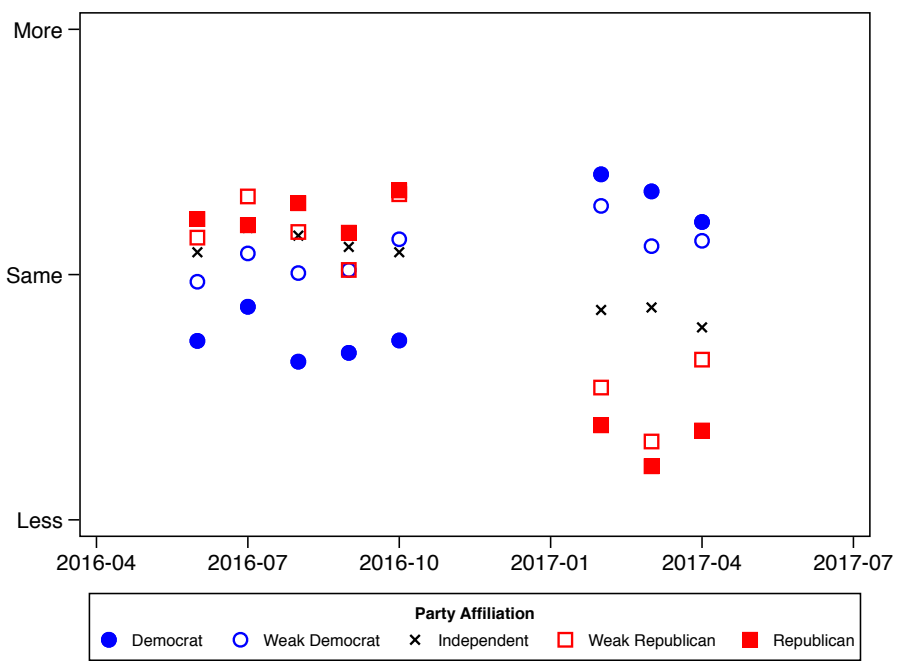

Notes: These graphs plot survey expectations on the future state of the economy by political affiliation. The data is from the University of Michigan Survey of Consumer Confidence (SCC). The upper panel shows the average response to the question "Looking ahead, which would you say is more likely - that in the country as a whole we'll have continuous good times during the next 5 years or so, or that we will have periods of widespread unemployment or depression, or what?" Responses range from 1 (worst) to 5 (best). The lower panel shows expectations on unemployment in a year relative to the current unemployment rate. 
Figure 2: Survey Expectations on Own Economic Circumstances Versus Overall Conditions

(a) Expected Own Income in 1 Year

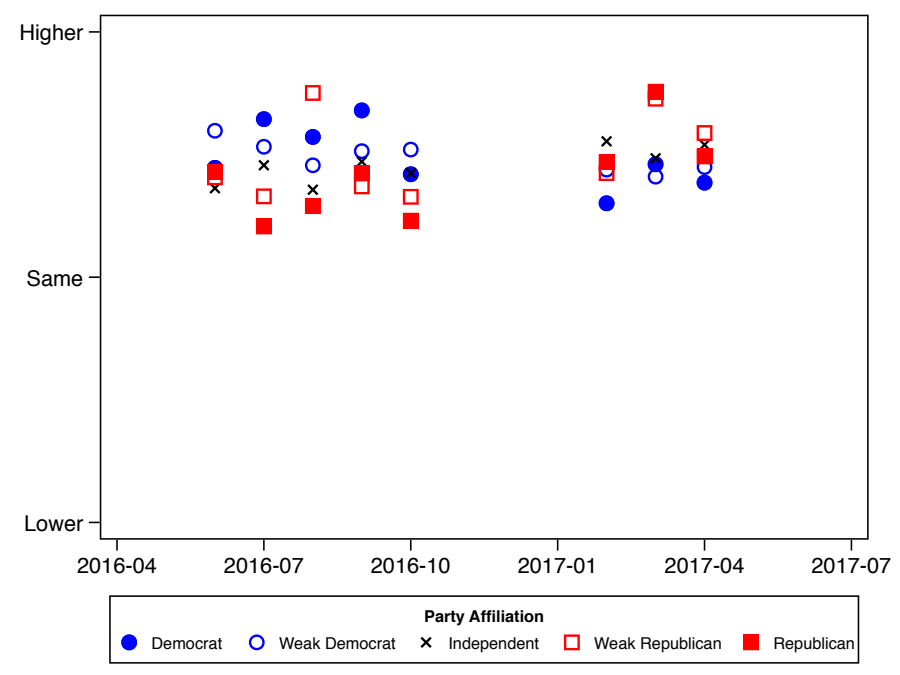

(b) Expected Business Conditions in 1 Year

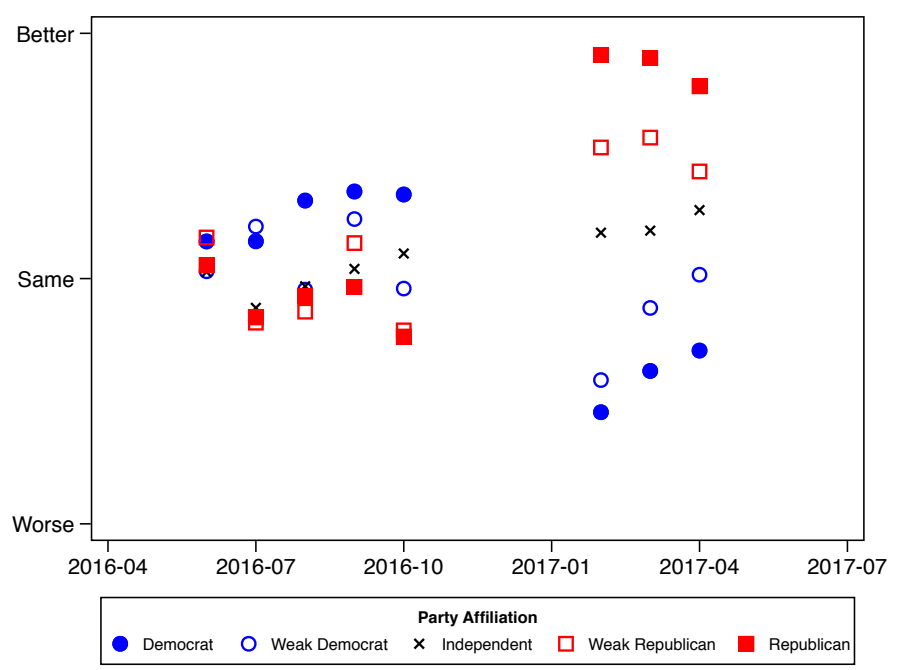

Notes: These graphs plot survey expectations on the future state of own economic circumstances and the overall economy by political affiliation. The data is from the University of Michigan Survey of Consumer Confidence (SCC). The upper panel shows the average response to the question "During the next 12 months, do you expect your income to be higher or lower than during the past year?" The lower panel shows expectations on whether business conditions overall will be better or worse in a year. 


\section{Figure 3: SCF Wealth Distribution in Population and RI Subsample}

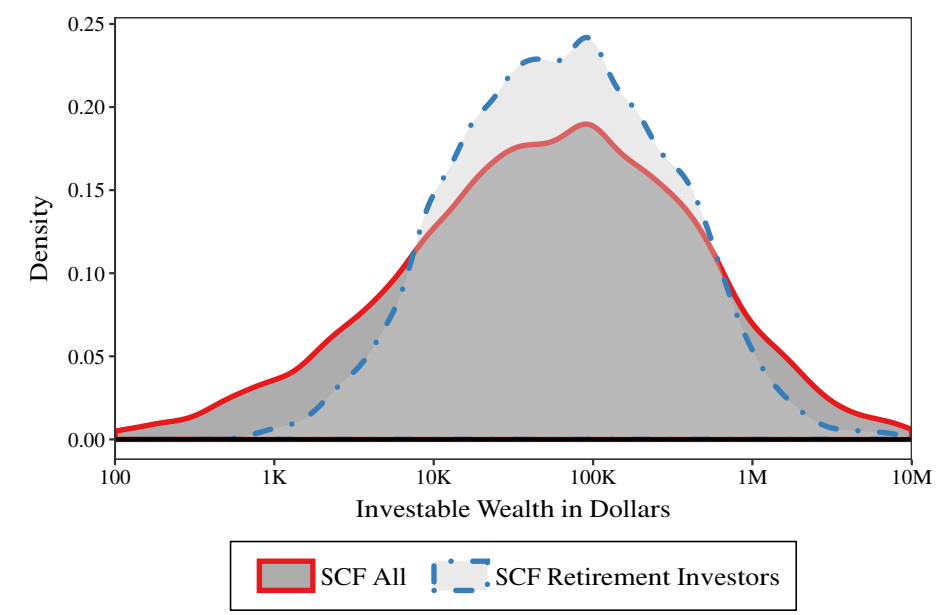

Notes: This figure plots the distribution of investable wealth (conditional on positive) in the full population and in the subsample of retirement investors (RIs) in the public version of the 2016 Survey of Consumer Finances (SCF). Investable wealth is defined as the sum of money market funds, stocks, bonds, pooled investment funds, retirement accounts, and other managed assets. To construct the RI subsample, we select households with age of the head between 25 and 64 and with quasi-liquid retirement wealth, and run quantile regressions of log retirement wealth on a second-order polynomial in age. We use the fitted 10th and 90th percentiles by age as retirement wealth cutoffs. 


\section{Figure 4: Wealth Distribution in Comparison to SCF}

\section{(a) Retirement Wealth}

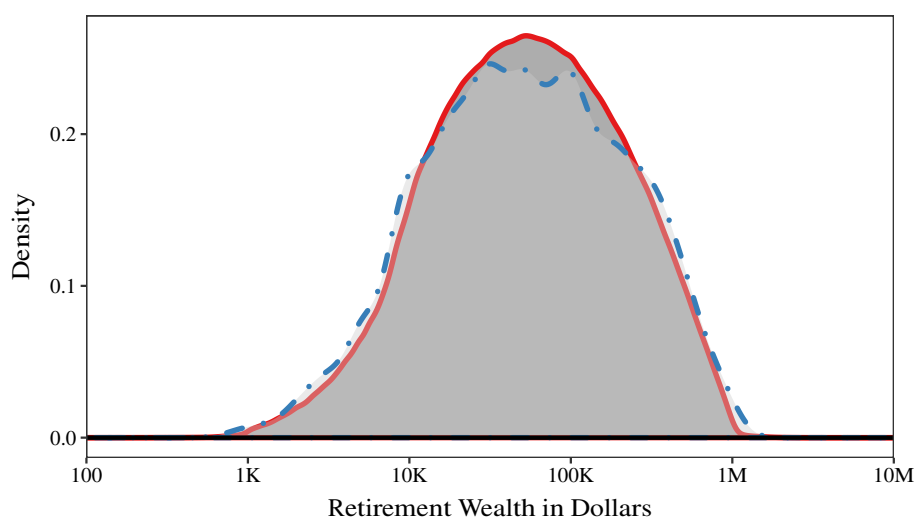

Sample

(b) Total Investable Wealth

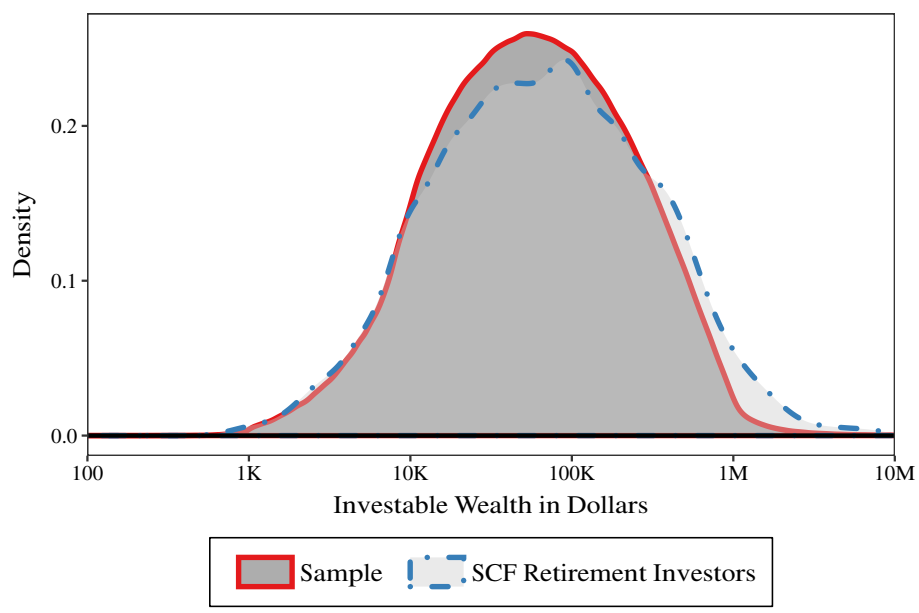

Notes: These figures plot the distributions of retirement wealth and total investable wealth, respectively, in our sample compared to the equivalent sample of RIs in the public version of the 2016 Survey of Consumer Finances (SCF). We select households with positive quasi-liquid retirement wealth and run quantile regressions of log retirement wealth on a second-order polynomial in age for households in the 2016 SCF. We use the fitted 10th and 90th percentiles by age as retirement wealth cutoffs in both datasets. We include households with age of the head between 25 and 64 and filter our sample on households that have portfolio holdings between $20 \%$ and $500 \%$ of initial assets in every month in the sample. 
Figure 5: Household Coverage in Sample

(a) Map of Household Coverage in Sample (Scrambled)

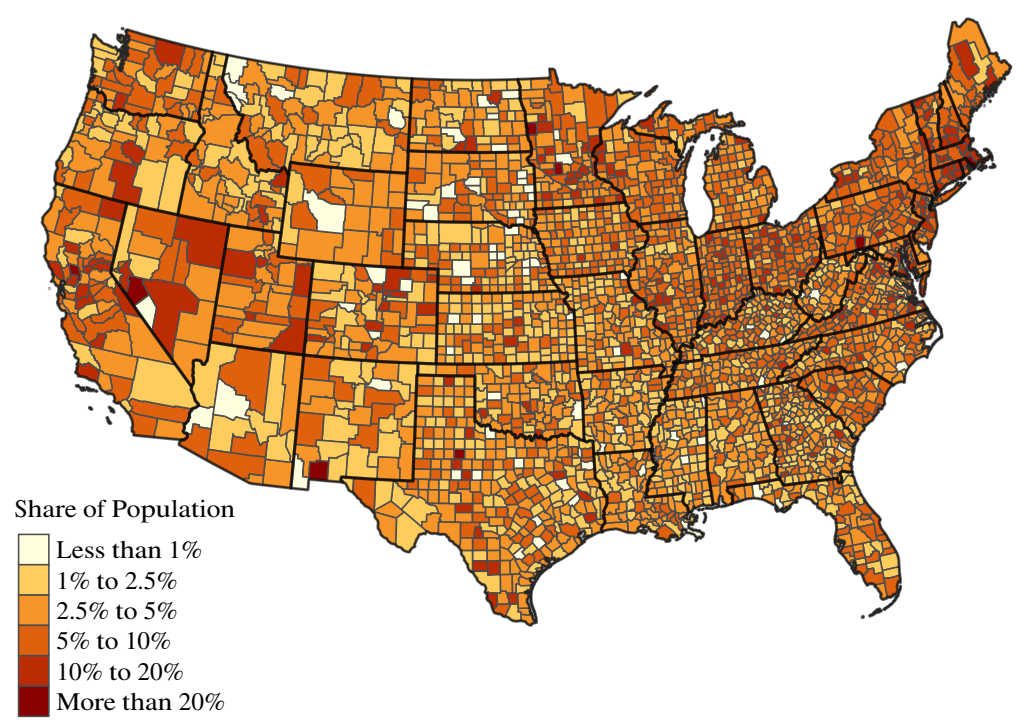

(b) Distribution of Household Coverage by County

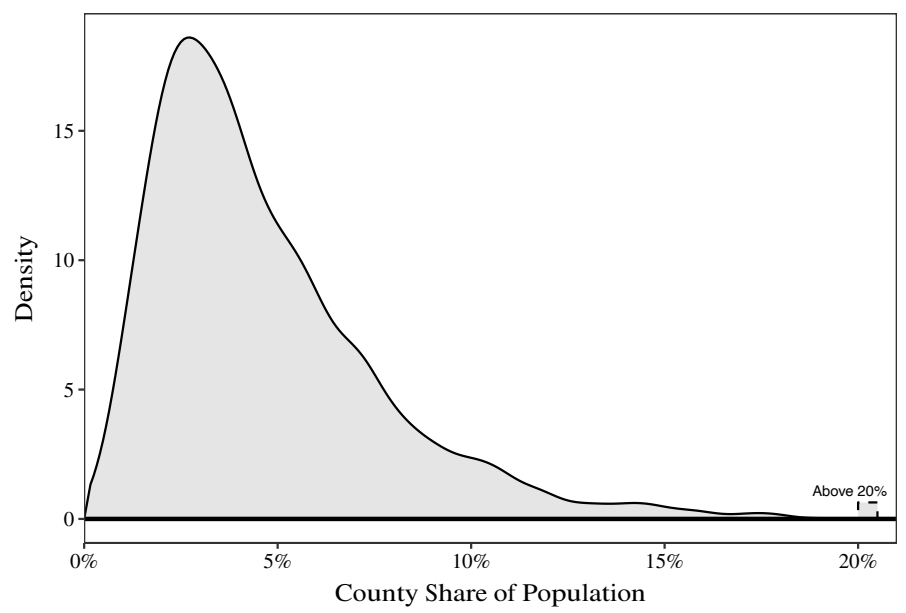

Notes: Panel (a) shows the geographical distribution of household coverage in our sample of RIs relative to the population total number of households by county from the 2011-2015 American Community Survey. We calculate the share for every county in the US and then randomly reallocate the shares across counties in each state for confidentiality reasons. Panel (b) plots the density of household coverage by county in our sample of RIs as a fraction of the population total number of households by county. 
Figure 6: Portfolio Equity Share by Zip Code Party Affiliation

(a) Equity Share, Equally Weighted Across Households

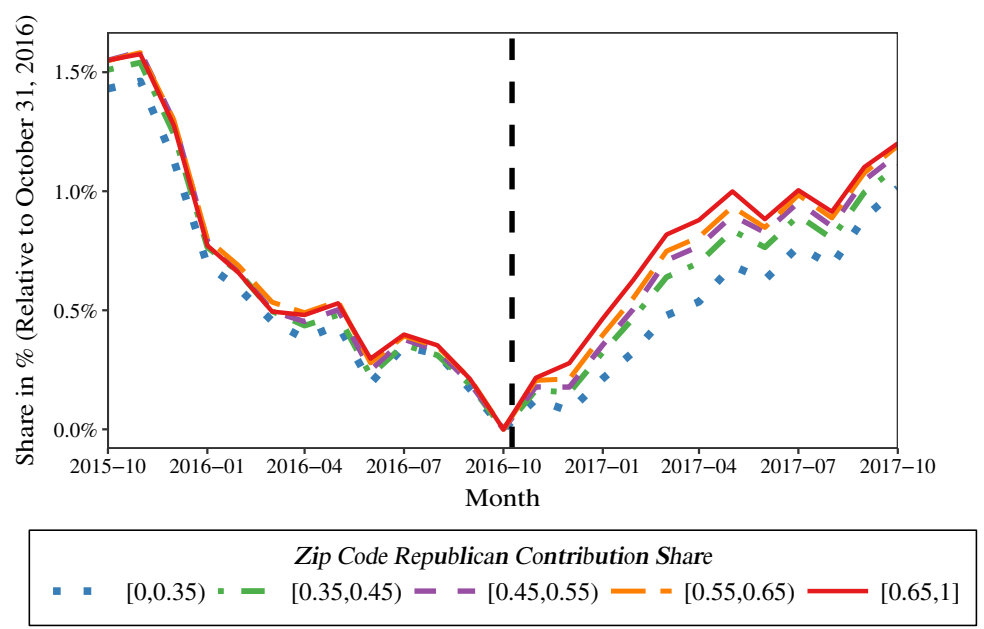

(b) Equity Share, Value Weighted Across Households

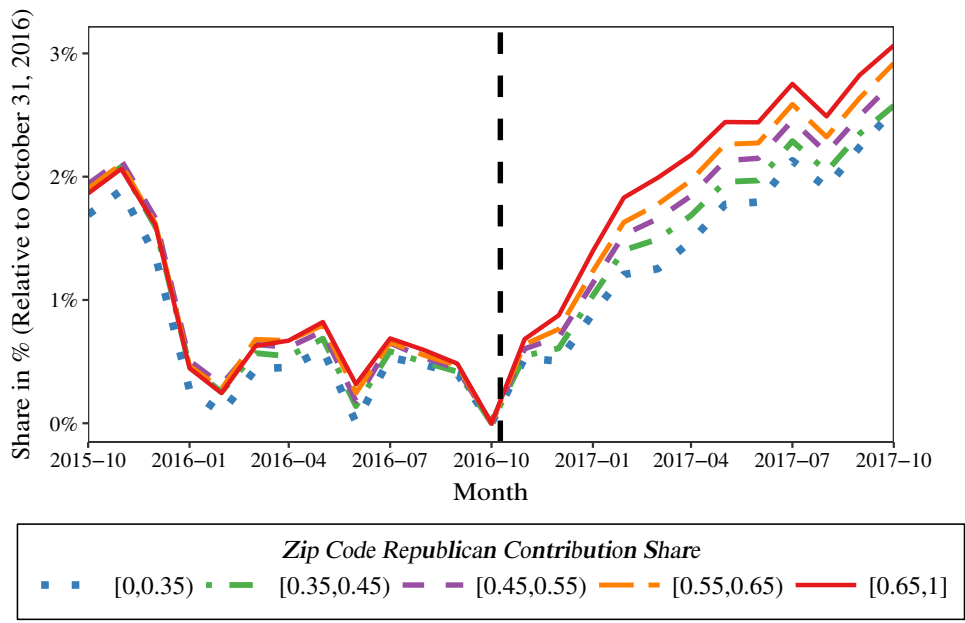

Notes: These graphs plot the average equity share of household portfolio assets in five groups by zip code party affiliation measured from political contributions, relative to the share by the end of October 2016. The sample is our full set of RI households. Average shares by group are equally weighted and asset weighted across households, respectively. 
Figure 7: Portfolio Allocations for Previously Active Sample

(a) Equity Share for Previously Active Sample

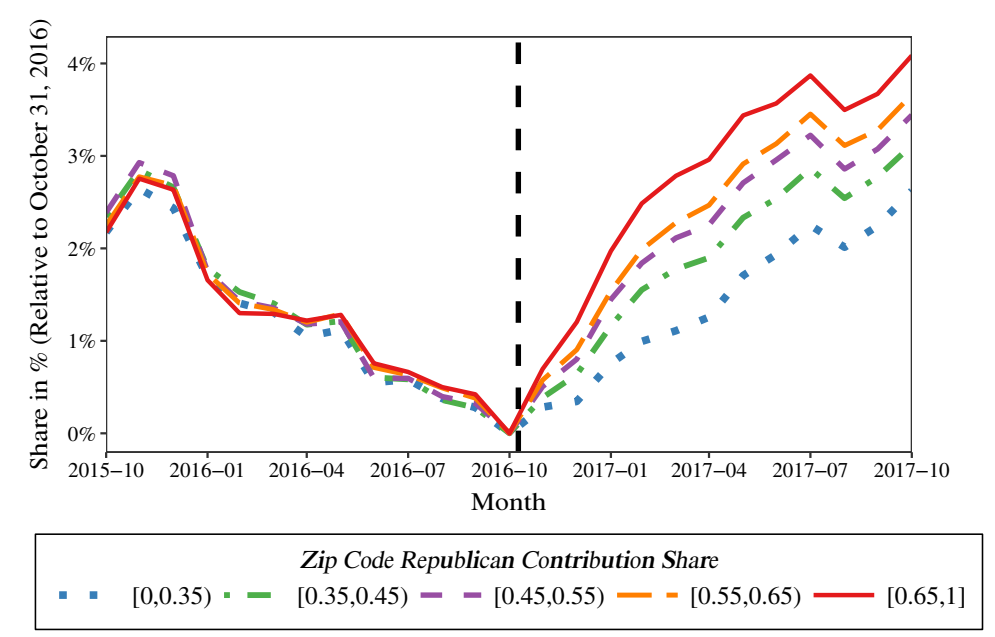

(b) Market Beta for Previously Active Sample

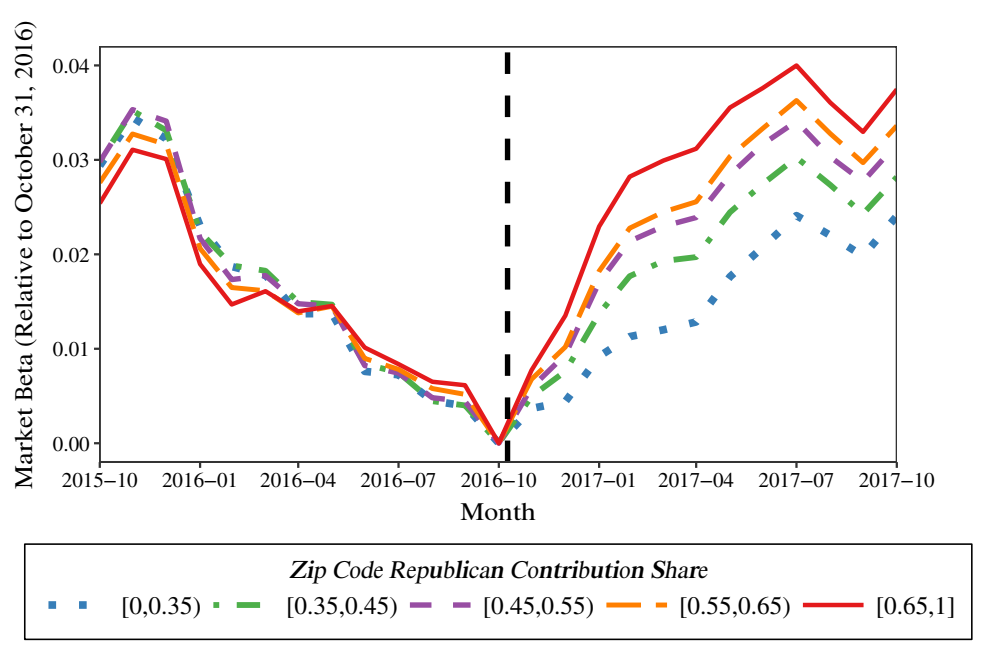

Notes: This figure plots the average equity share and market beta, respectively, of household portfolio assets in five groups by zip code party affiliation measured from political contributions, relative to the share by the end of October 2016. The sample is the subset of RI households with an active portfolio reallocation in the prior year (11.1\% of all RIs). Average allocations by group are equally weighted across households. 
Figure 8: Active Portfolio Rebalancing by Zip Code Political Affiliation

(a) Equity Share of Price-Constant Portfolios

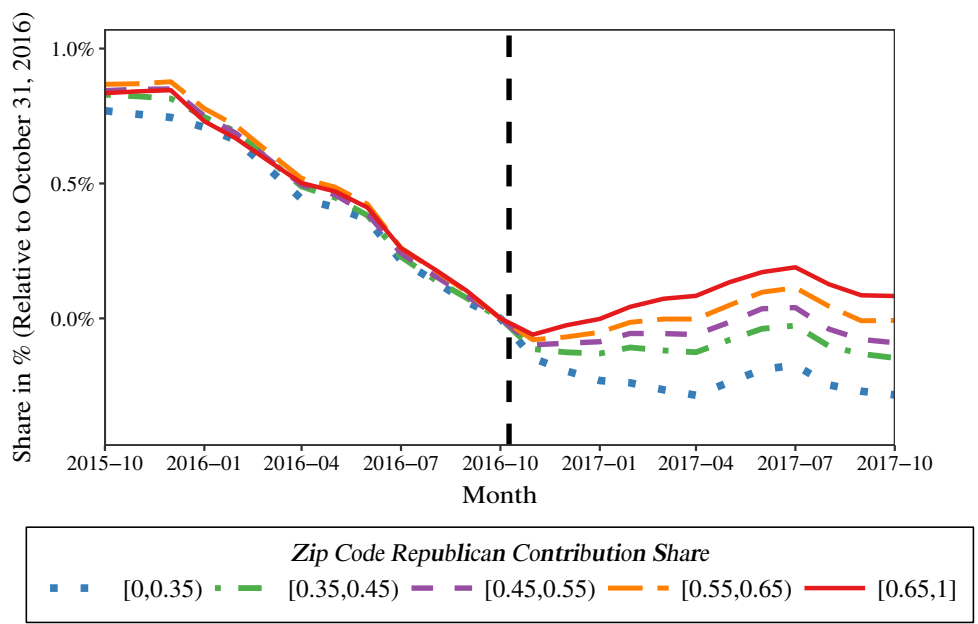

(b) Market Beta of Price-Constant Portfolios

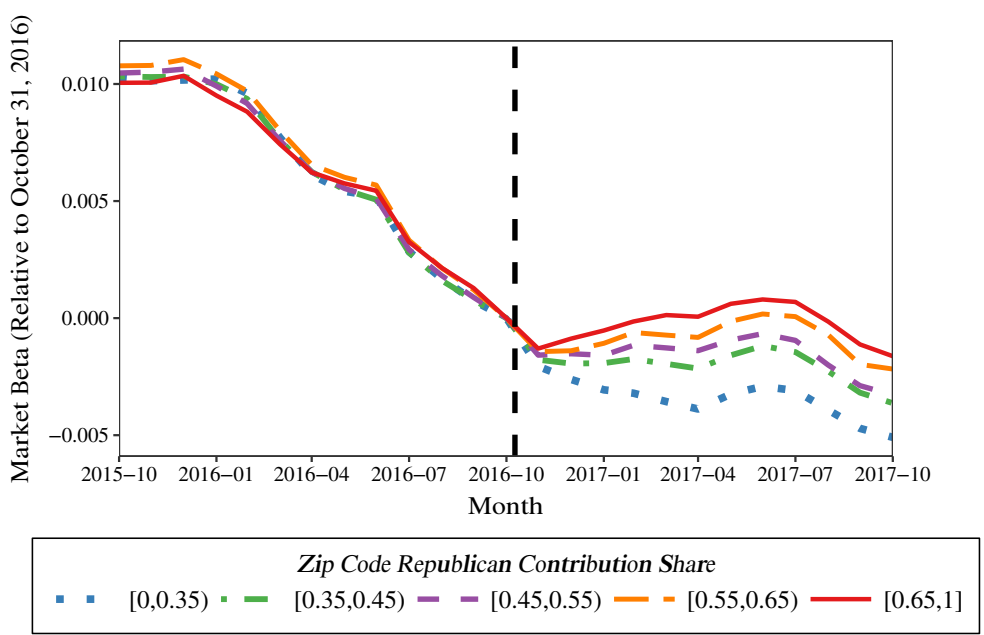

Notes: In this figure, we plot the average equity share and average portfolio market beta, respectively, of hypothetical price-constant household portfolios in five groups by zip code party affiliation measured from political contributions, relative to the share by the end of October 2016. The portfolio measures are calculated for a hypothetical portfolio that is insensitive to passive appreciations. To construct these price-constant portfolios, we start with initial household holdings as of October 2015, assume there are no price changes, and keep track of cumulative monthly dollar inflows and outflows at the asset level. For each month we then calculate the equity share from this hypothetical portfolio. The sample is our full set of RI households. Average allocations by group are equally weighted across households. 
Figure 9: Panel Regression Coefficients of Equity Shares on Likely Political Affiliation

(a) Equity Share (Baseline Controls)

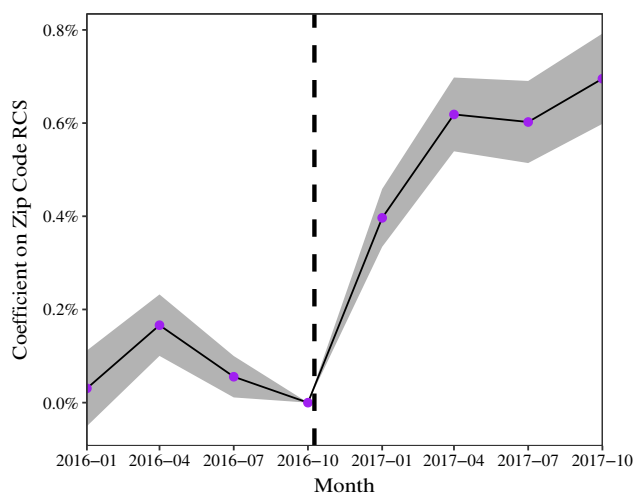

(c) Equity Share (Employer-County-Period FE)

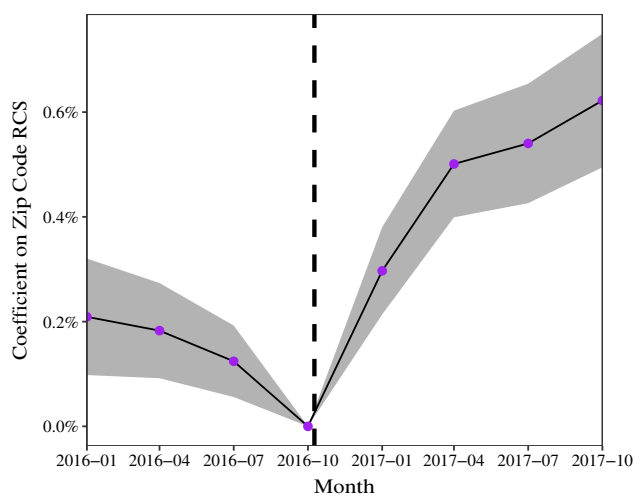

(b) Price-Constant Equity Share (Baseline Controls)

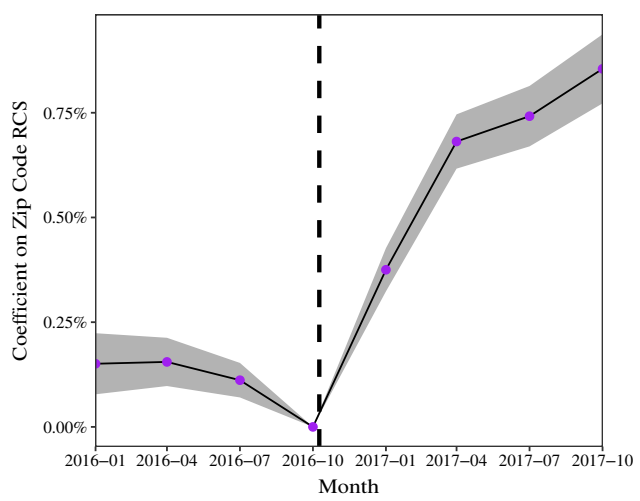

(d) Price-Constant Equity Share (EmployerCounty-Period FE)

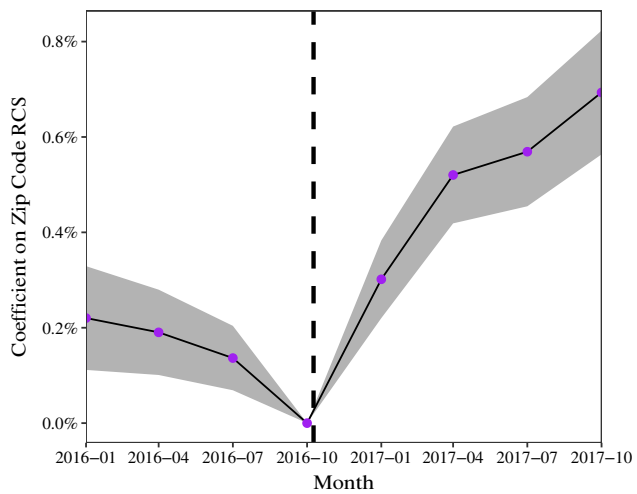

Notes: This figure plots the estimated regression coefficients of quarterly household portfolio equity shares on the zip code Republican contribution share, for the three quarters prior to the election and the four quarters following the election, relative to allocations just before the election. In panels (a) and (c) we report the results for the observed equity share, and in panels (b) and (d) we report the results for the equity share of hypothetical price-constant portfolios that are insensitive to passive appreciations and are driven by trading only. The baseline controls are the initial equity share, age, gender, marital status, log initial financial wealth, log labor income in 2015, the initial winning and losing sectors shares of equity, and zip code house price growth (2010-2015), all interacted by quarterly indicators, as well as individual fixed effects. In panels (c) and (d) we additionally control for employer $\times$ county $\times$ quarter fixed effects. The sample is our full set of RI households between October 2015 and October 2017, for which we observe the complete set of controls ( $27.7 \%$ of all RIs). Standard errors are clustered at the zip code level. 
Figure 10: Equity Share of Price-Constant Portfolios by Zip Code Party Affiliation, Small Versus Large Changes

(a) Restricting to Cumulative Changes of at Least $10 \%$

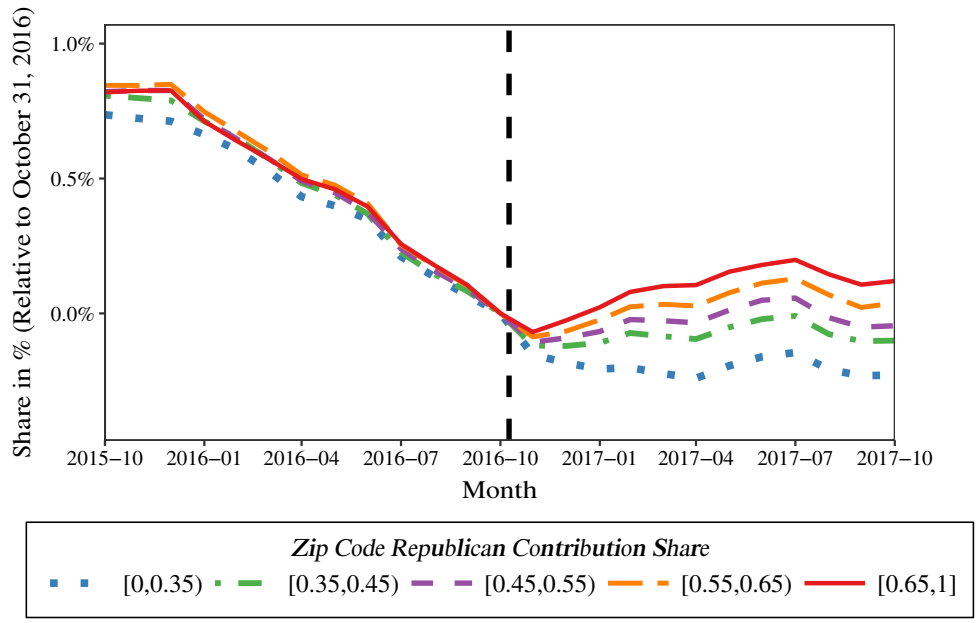

(b) Restricting to Cumulative Changes of at Most 10\%

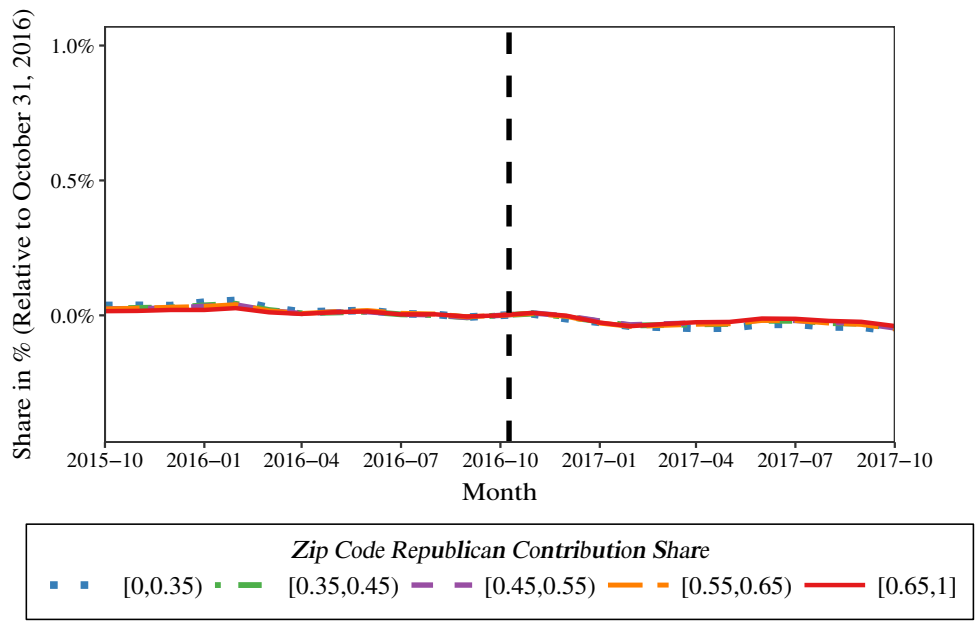

Notes: These graphs plot the average equity share of hypothetical price-constant household portfolios in five groups by zip code party affiliation measured from political contributions, relative to the share by the end of October 2016. The price-constant equity share is calculated for a hypothetical portfolio that is insensitive to passive appreciations and is driven by trading only. In panel (a), we only include cumulative changes relative to October 2016 of at least $10 \%$, and set portfolio changes to zero otherwise. In panel (b), we only include cumulative changes of at most $10 \%$. The sample is our full set of RI households. Average shares by group are equally weighted across households. 
Figure 11: Trading Volume Relative to Initial Balance

(a) All and Active Trading Volume for Aggregate Sample

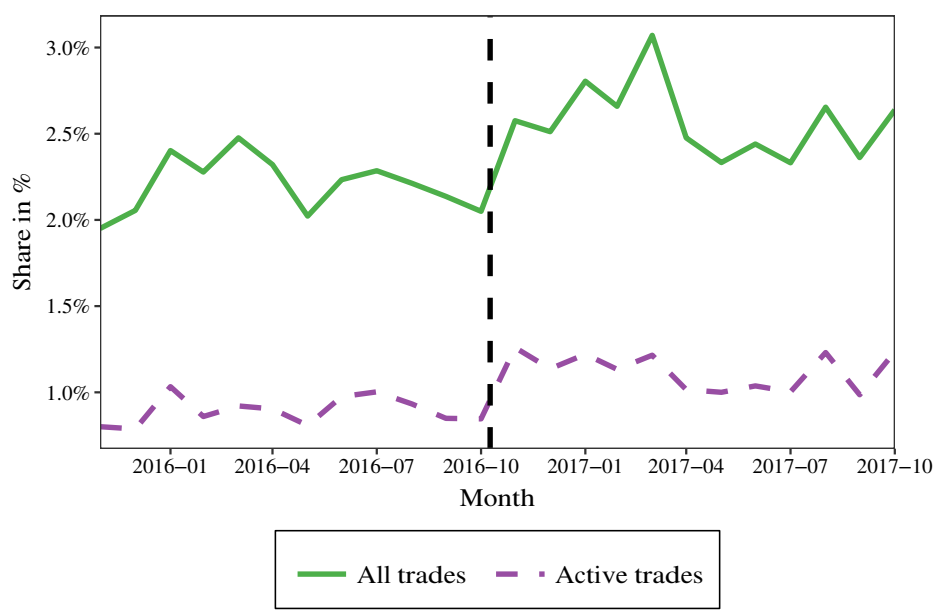

(b) Trading Volume by Zip Code Political Affiliation

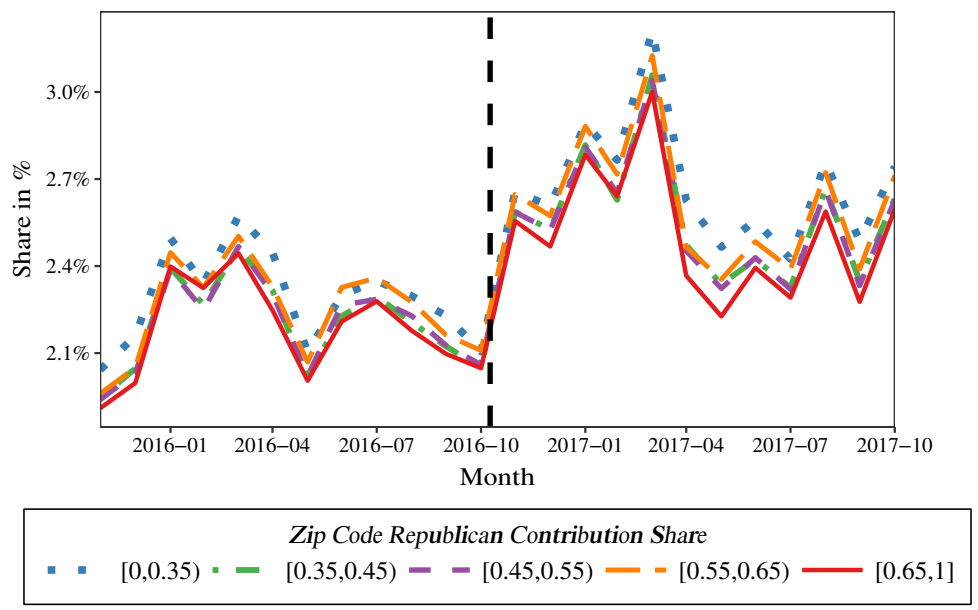

Notes: This figure plots average trading volume as a fraction of initial balance, where volume is defined as one half times the sum of the absolute values of buy and sell transactions. The upper panel plots the volume of all trades and of active (investor-initiated) trades or exchanges. The lower panel plots the volume of all trades in five groups by zip code party affiliation measured from political contributions. The sample is our full set of RI households. Averages are equally weighted across households. 
Figure 12: Household Net Flow Rates by Zip Code Party Affiliation

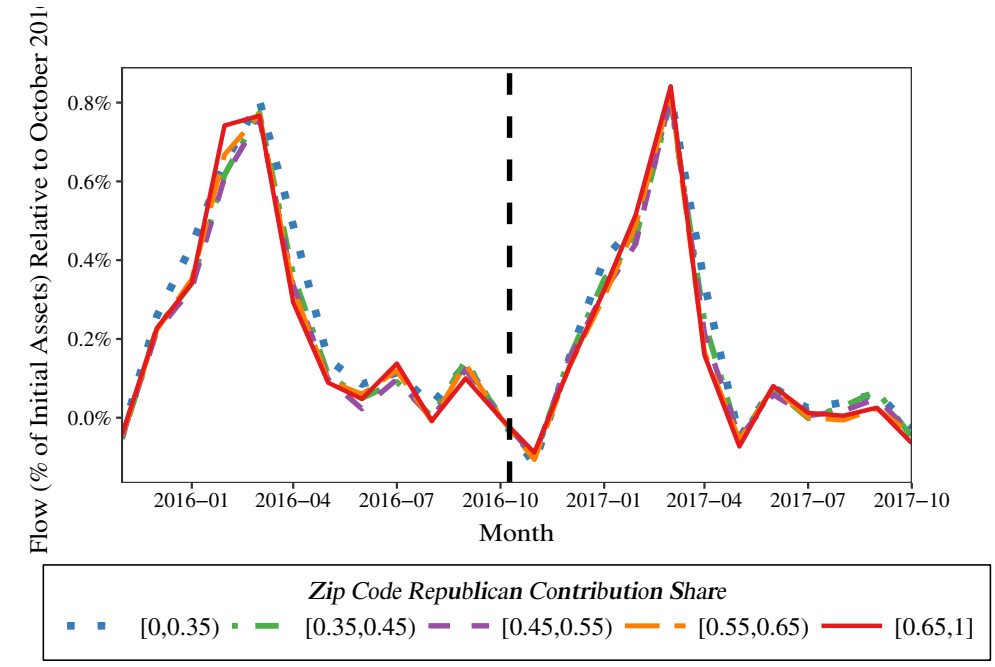

Notes: This graph plots average net flows as a fraction of initial financial wealth in five groups by zip code party affiliation measured from political contributions, relative to the savings rate in October 2016. Net flows are defined as total deposits minus withdrawals. The sample is our full set of RI households. Average flow rates by group are equally weighted across households. 
Figure 13: Equity Composition of Price-Constant Portfolios by Zip Code Party Affiliation

(a) Market Beta of Equity by Zip Code Party Affiliation

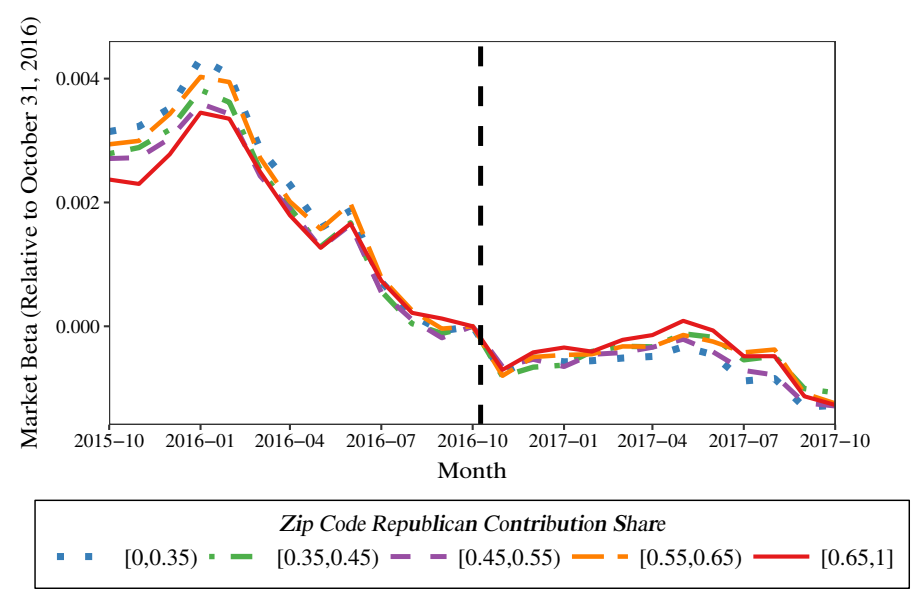

(b) International Share of Equity by Zip Code Party Affiliation

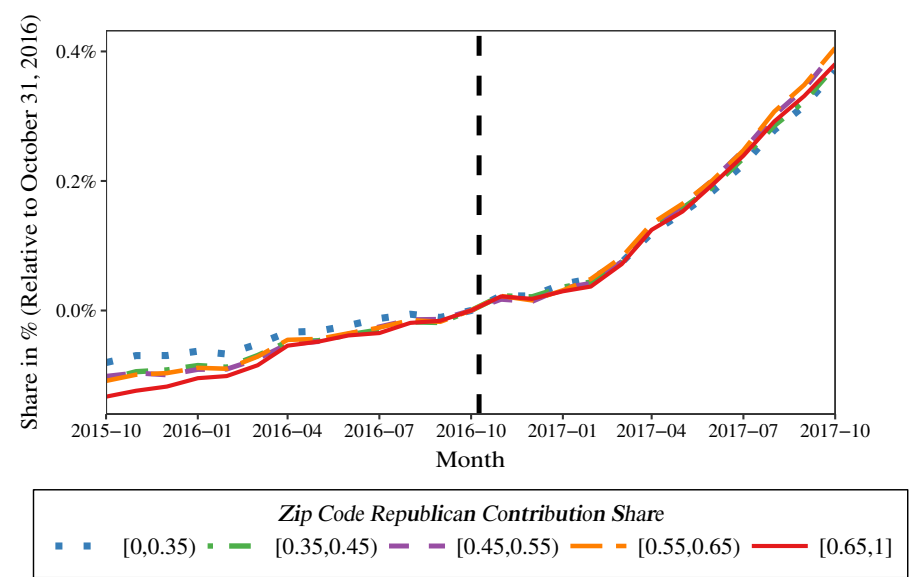

Notes: These graphs plot the average price-constant market beta of household equity assets and the average priceconstant international share of household equity products, respectively, in five groups by zip code party affiliation measured from political contributions, relative to the share by the end of October 2016. The price-constant portfolio measures are calculated for a hypothetical portfolio that is insensitive to passive appreciations and is driven by trading only. Market betas are obtained by regressing monthly fund or security excess returns on the value-weighted CRSP market excess return over the period 2006-2019 with at least 24 observations. International equity holdings consist of individual foreign company stocks and funds that invest in international equity. The sample is our full set of households. Averages by group are equally weighted across households. 
Table 1: Summary Statistics on Portfolios of Retirement Investors Sample

\begin{tabular}{|c|c|c|c|c|c|c|c|}
\hline & \multirow[b]{2}{*}{ All } & \multirow[b]{2}{*}{ SCF } & \multicolumn{5}{|c|}{ Republican contribution share } \\
\hline & & & {$[0,0.35)$} & {$[0.35,0.45)$} & {$[0.45,0.55)$} & {$[0.55,0.65)$} & {$[0.65,1]$} \\
\hline Share of sample & $100.0 \%$ & & $44.8 \%$ & $18.0 \%$ & $14.8 \%$ & $12.5 \%$ & $9.9 \%$ \\
\hline \multicolumn{8}{|l|}{ Average wealth (in 1,000 USD) } \\
\hline Total investable wealth & 138.1 & 232.8 & 147.9 & 138.3 & 136.4 & 140.1 & 128.7 \\
\hline Retirement wealth & 116.4 & 122.5 & 118.2 & 119.3 & 118.6 & 121.1 & 114.5 \\
\hline \multicolumn{8}{|l|}{ Median wealth (in 1,000 USD) } \\
\hline Total investable wealth & 56.7 & 66.0 & 58.2 & 58.1 & 57.7 & 59.5 & 55.0 \\
\hline Retirement wealth & 53.7 & 51.0 & 54.1 & 55.1 & 55.1 & 56.8 & 53.0 \\
\hline \multicolumn{8}{|l|}{ Average allocation } \\
\hline Equity share & $71.2 \%$ & $53.0 \%$ & $71.5 \%$ & $71.2 \%$ & $71.1 \%$ & $71.1 \%$ & $70.7 \%$ \\
\hline Bond share & $19.5 \%$ & $44.5 \%$ & $18.2 \%$ & $19.6 \%$ & $20.0 \%$ & $20.0 \%$ & $20.8 \%$ \\
\hline Cash share & $8.6 \%$ & $2.5 \%$ & $9.5 \%$ & $8.5 \%$ & $8.3 \%$ & $8.2 \%$ & $7.8 \%$ \\
\hline Market beta & 0.743 & & 0.746 & 0.743 & 0.743 & 0.744 & 0.741 \\
\hline \multicolumn{8}{|l|}{ Average allocation (weighted) } \\
\hline Equity share & $68.6 \%$ & $59.8 \%$ & $69.0 \%$ & $68.8 \%$ & $68.5 \%$ & $68.2 \%$ & $67.7 \%$ \\
\hline Bond share & $20.6 \%$ & $36.8 \%$ & $19.1 \%$ & $20.8 \%$ & $21.3 \%$ & $21.3 \%$ & $22.5 \%$ \\
\hline Cash share & $9.7 \%$ & $3.4 \%$ & $10.7 \%$ & $9.3 \%$ & $9.1 \%$ & $9.5 \%$ & $8.8 \%$ \\
\hline Market beta & 0.717 & & 0.721 & 0.718 & 0.715 & 0.713 & 0.709 \\
\hline \multicolumn{8}{|l|}{ Average allocation of equity } \\
\hline Market beta & 1.007 & & 1.007 & 1.006 & 1.006 & 1.008 & 1.011 \\
\hline Fund share & $90.3 \%$ & & $90.5 \%$ & $90.3 \%$ & $90.3 \%$ & $89.7 \%$ & $89.7 \%$ \\
\hline Winning sectors share & $5.4 \%$ & & $4.8 \%$ & $5.4 \%$ & $5.6 \%$ & $6.1 \%$ & $6.5 \%$ \\
\hline Losing sectors share & $4.2 \%$ & & $4.7 \%$ & $4.3 \%$ & $4.1 \%$ & $4.0 \%$ & $3.5 \%$ \\
\hline International share & $6.9 \%$ & & $6.9 \%$ & $7.2 \%$ & $7.0 \%$ & $7.1 \%$ & $6.9 \%$ \\
\hline
\end{tabular}

Notes: This table presents summary statistics on wealth and portfolio allocations of our retirement investors (RI) sample as of October 31, 2016, for the full sample and for five groups by zip code party affiliation measured from political contributions. We select households with quasi-liquid retirement wealth and run quantile regressions of log retirement wealth on a second-order polynomial in age for households in the 2016 Survey of Consumer Finances (SCF). We use the fitted 10th and 90th percentiles by age as retirement wealth cutoffs at the initial date. We include households with age of the head between 25 and 64 years and create a balanced panel by filtering on households that have portfolio holdings between $20 \%$ and $500 \%$ of initial assets over the sample period from October 31, 2015 to October 31, 2017. All funds and individual securities are characterized as equity, bonds, cash or cash-like assets, or alternative assets. Mixed funds are subdivided into equity and bonds based on their asset holdings. Market betas are obtained by regressing monthly fund or security excess returns on the value-weighted CRSP market excess return over the period 2006-2019 with at least 24 observations. Winning (losing) sectors are sectors that did relatively well (poorly) between the election and the end of 2016. International equity holdings consist of individual foreign company stocks and funds that invest in international equity. 
Table 2: Summary Statistics on Demographics of Retirement Investors Sample

\begin{tabular}{|c|c|c|c|c|c|c|c|}
\hline & \multirow[b]{2}{*}{ All } & \multirow[b]{2}{*}{ SCF } & \multicolumn{5}{|c|}{ Republican contribution share } \\
\hline & & & {$[0,0.35)$} & {$[0.35,0.45)$} & {$[0.45,0.55)$} & {$[0.55,0.65)$} & {$[0.65,1]$} \\
\hline \multicolumn{8}{|l|}{$\begin{array}{l}\text { Percentage of sample } \\
\text { with observed }\end{array}$} \\
\hline Gender & $94.8 \%$ & & $94.8 \%$ & $95.1 \%$ & $95.0 \%$ & $95.1 \%$ & $94.7 \%$ \\
\hline Marital status & $87.0 \%$ & & $85.7 \%$ & $87.3 \%$ & $87.8 \%$ & $87.9 \%$ & $88.7 \%$ \\
\hline Non-retirement assets & $16.8 \%$ & & $19.0 \%$ & $16.8 \%$ & $16.0 \%$ & $16.6 \%$ & $14.7 \%$ \\
\hline Employer industry & $66.6 \%$ & & $63.3 \%$ & $67.0 \%$ & $68.0 \%$ & $68.1 \%$ & $70.1 \%$ \\
\hline Labor income in 2015 & $49.9 \%$ & & $45.6 \%$ & $50.8 \%$ & $51.5 \%$ & $52.6 \%$ & $55.1 \%$ \\
\hline Income growth over 2016-17 & $44.2 \%$ & & $39.7 \%$ & $45.2 \%$ & $45.9 \%$ & $47.1 \%$ & $49.3 \%$ \\
\hline Active change in prior year & $11.1 \%$ & & $11.7 \%$ & $11.1 \%$ & $11.1 \%$ & $11.4 \%$ & $10.7 \%$ \\
\hline Average age (in years) & 46.0 & 46.3 & 45.2 & 46.3 & 46.6 & 46.7 & 46.8 \\
\hline$\%$ Female & $43.8 \%$ & $19.9 \%$ & $46.5 \%$ & $44.6 \%$ & $43.2 \%$ & $41.2 \%$ & $38.0 \%$ \\
\hline$\%$ Married & $73.1 \%$ & $69.5 \%$ & $69.3 \%$ & $73.9 \%$ & $75.3 \%$ & $77.0 \%$ & $78.1 \%$ \\
\hline \multicolumn{8}{|l|}{$\begin{array}{l}\text { Labor income in } 2016 \\
\text { (in 1,000 USD) }\end{array}$} \\
\hline Average & 101.2 & 102.8 & 115.7 & 99.1 & 96.1 & 98.6 & 91.6 \\
\hline Median & 77.3 & 81.0 & 84.0 & 77.9 & 76.3 & 78.0 & 74.6 \\
\hline 10th percentile & 37.2 & 33.4 & 38.3 & 37.6 & 37.2 & 38.0 & 37.3 \\
\hline 90th percentile & 172.4 & 182.3 & 200.3 & 169.1 & 162.1 & 166.3 & 152.2 \\
\hline
\end{tabular}

Notes: This table presents summary statistics on demographics and composition of our retirement investors (RI) sample as of October 31, 2016, for the full sample and for five groups by zip code party affiliation measured from political contributions. We select households with quasi-liquid retirement wealth and run quantile regressions of log retirement wealth on a second-order polynomial in age for households in the 2016 Survey of Consumer Finances (SCF). We use the fitted 10th and 90th percentiles by age as retirement wealth cutoffs at the initial date. We include households with age of the head between 25 and 64 years and create a balanced panel by filtering on households that have portfolio holdings between 20\% and 500\% of initial assets over the sample period from October 31, 2015 to October 31, 2017. 
Table 3: Regressions of Price-Constant Equity Share Changes on Likely Political Affiliation

\begin{tabular}{|c|c|c|c|c|c|c|c|c|}
\hline & \multicolumn{8}{|c|}{ One-year difference in price-constant equity share (in \%), all households } \\
\hline & (1) & (2) & (3) & (4) & (5) & (6) & (7) & (8) \\
\hline Zip code Republican contribution share & $\begin{array}{l}-0.343 \\
(0.042)\end{array}$ & $\begin{array}{l}-0.225 \\
(0.039)\end{array}$ & $\begin{array}{l}-0.232 \\
(0.039)\end{array}$ & $\begin{array}{l}-0.097 \\
(0.037)\end{array}$ & $\begin{array}{l}-0.070 \\
(0.038)\end{array}$ & $\begin{array}{l}-0.148 \\
(0.043)\end{array}$ & $\begin{array}{l}-0.221 \\
(0.054)\end{array}$ & $\begin{array}{l}-0.160 \\
(0.059)\end{array}$ \\
\hline Zip code Republican contribution share $\times$ Post & $\begin{array}{l}1.071 \\
(0.066)\end{array}$ & $\begin{array}{l}1.061 \\
(0.057)\end{array}$ & $\begin{array}{c}1.062 \\
(0.057)\end{array}$ & $\begin{array}{c}0.932 \\
(0.056)\end{array}$ & $\begin{array}{c}0.900 \\
(0.059)\end{array}$ & $\begin{array}{c}0.929 \\
(0.064)\end{array}$ & $\begin{array}{c}0.969 \\
(0.084)\end{array}$ & $\begin{array}{c}0.859 \\
(0.091)\end{array}$ \\
\hline Lagged equity share & & $\begin{array}{r}-10.273 \\
(0.060)\end{array}$ & $\begin{array}{c}-10.273 \\
(0.060)\end{array}$ & $\begin{array}{r}-10.392 \\
(0.060)\end{array}$ & $\begin{array}{r}-10.798 \\
(0.062)\end{array}$ & $\begin{array}{l}-10.291 \\
(0.060)\end{array}$ & $\begin{array}{r}-10.342 \\
(0.060)\end{array}$ & $\begin{array}{r}-10.805 \\
(0.068)\end{array}$ \\
\hline Lagged equity share $\times$ Post & & $\begin{array}{l}-3.888 \\
(0.077)\end{array}$ & $\begin{array}{l}-3.890 \\
(0.077)\end{array}$ & $\begin{array}{l}-3.856 \\
(0.077)\end{array}$ & $\begin{array}{l}-3.815 \\
(0.079)\end{array}$ & $\begin{array}{l}-3.880 \\
(0.077)\end{array}$ & $\begin{array}{l}-3.870 \\
(0.077)\end{array}$ & $\begin{array}{l}-3.799 \\
(0.085)\end{array}$ \\
\hline Age & & $\begin{array}{l}-0.104 \\
(0.001)\end{array}$ & $\begin{array}{l}-0.104 \\
(0.001)\end{array}$ & $\begin{array}{l}-0.104 \\
(0.001)\end{array}$ & $\begin{array}{l}-0.106 \\
(0.001)\end{array}$ & $\begin{array}{l}-0.104 \\
(0.001)\end{array}$ & $\begin{array}{l}-0.104 \\
(0.001)\end{array}$ & $\begin{array}{l}-0.105 \\
(0.001)\end{array}$ \\
\hline Age $\times$ Post & & $\begin{array}{l}-0.021 \\
(0.001)\end{array}$ & $\begin{array}{l}-0.020 \\
(0.001)\end{array}$ & $\begin{array}{l}-0.021 \\
(0.001)\end{array}$ & $\begin{array}{l}-0.023 \\
(0.001)\end{array}$ & $\begin{array}{l}-0.022 \\
(0.001)\end{array}$ & $\begin{array}{l}-0.021 \\
(0.001)\end{array}$ & $\begin{array}{l}-0.024 \\
(0.001)\end{array}$ \\
\hline Female & & $\begin{array}{c}0.299 \\
(0.012)\end{array}$ & $\begin{array}{c}0.301 \\
(0.012)\end{array}$ & $\begin{array}{c}0.166 \\
(0.013)\end{array}$ & $\begin{array}{c}0.140 \\
(0.013)\end{array}$ & $\begin{array}{c}0.284 \\
(0.012)\end{array}$ & $\begin{array}{c}0.271 \\
(0.012)\end{array}$ & $\begin{array}{c}0.144 \\
(0.015)\end{array}$ \\
\hline Female $\times$ Post & & $\begin{array}{l}-0.509 \\
(0.019)\end{array}$ & $\begin{array}{l}-0.502 \\
(0.019)\end{array}$ & $\begin{array}{l}-0.415 \\
(0.021)\end{array}$ & $\begin{array}{l}-0.394 \\
(0.021)\end{array}$ & $\begin{array}{l}-0.495 \\
(0.019)\end{array}$ & $\begin{array}{l}-0.487 \\
(0.019)\end{array}$ & $\begin{array}{l}-0.378 \\
(0.024)\end{array}$ \\
\hline Married & & $\begin{array}{c}0.037 \\
(0.014)\end{array}$ & $\begin{array}{c}0.037 \\
(0.014)\end{array}$ & $\begin{array}{c}0.047 \\
(0.014)\end{array}$ & $\begin{array}{c}0.051 \\
(0.014)\end{array}$ & $\begin{array}{c}0.044 \\
(0.014)\end{array}$ & $\begin{array}{c}0.043 \\
(0.014)\end{array}$ & $\begin{array}{c}0.048 \\
(0.016)\end{array}$ \\
\hline Married $\times$ Post & & $\begin{array}{c}0.120 \\
(0.021)\end{array}$ & $\begin{array}{c}0.121 \\
(0.021)\end{array}$ & $\begin{array}{c}0.096 \\
(0.021)\end{array}$ & $\begin{array}{c}0.092 \\
(0.022)\end{array}$ & $\begin{array}{c}0.107 \\
(0.021)\end{array}$ & $\begin{array}{c}0.101 \\
(0.021)\end{array}$ & $\begin{array}{c}0.092 \\
(0.025)\end{array}$ \\
\hline Log wealth & & $\begin{array}{l}-0.233 \\
(0.007)\end{array}$ & $\begin{array}{l}-0.234 \\
(0.007)\end{array}$ & $\begin{array}{l}-0.224 \\
(0.007)\end{array}$ & $\begin{array}{l}-0.215 \\
(0.007)\end{array}$ & $\begin{array}{l}-0.234 \\
(0.007)\end{array}$ & $\begin{array}{l}-0.230 \\
(0.007)\end{array}$ & $\begin{array}{l}-0.211 \\
(0.008)\end{array}$ \\
\hline Log wealth $\times$ Post & & $\begin{array}{c}0.245 \\
(0.011)\end{array}$ & $\begin{array}{c}0.243 \\
(0.011)\end{array}$ & $\begin{array}{c}0.236 \\
(0.011)\end{array}$ & $\begin{array}{c}0.227 \\
(0.011)\end{array}$ & $\begin{array}{c}0.247 \\
(0.011)\end{array}$ & $\begin{array}{c}0.240 \\
(0.011)\end{array}$ & $\begin{array}{c}0.228 \\
(0.012)\end{array}$ \\
\hline Log labor income 2015 & & $\begin{array}{c}0.045 \\
(0.013)\end{array}$ & $\begin{array}{c}0.044 \\
(0.013)\end{array}$ & $\begin{array}{c}0.062 \\
(0.014)\end{array}$ & $\begin{array}{c}0.087 \\
(0.015)\end{array}$ & $\begin{array}{c}0.049 \\
(0.013)\end{array}$ & $\begin{array}{c}0.058 \\
(0.013)\end{array}$ & $\begin{array}{c}0.085 \\
(0.017)\end{array}$ \\
\hline Log labor income $2015 \times$ Post & & $\begin{array}{c}0.282 \\
(0.021)\end{array}$ & $\begin{array}{c}0.286 \\
(0.021)\end{array}$ & $\begin{array}{c}0.261 \\
(0.022)\end{array}$ & $\begin{array}{c}0.227 \\
(0.024)\end{array}$ & $\begin{array}{c}0.284 \\
(0.021)\end{array}$ & $\begin{array}{c}0.273 \\
(0.021)\end{array}$ & $\begin{array}{c}0.193 \\
(0.027)\end{array}$ \\
\hline Controls by year & & & & & & & & \\
\hline $\begin{array}{l}\text { Baseline } \\
\text { Labor income growth 2016-17 } \\
\text { Zip code house price growth 2015-17 }\end{array}$ & & Y & $\begin{array}{l}Y \\
Y \\
Y\end{array}$ & Y & $\mathrm{Y}$ & Y & Y & Y \\
\hline Employer industry & & & & $\mathrm{Y}$ & & & & \\
\hline $\begin{array}{l}\text { Employer } \\
\text { State }\end{array}$ & & & & & Y & $Y$ & & \\
\hline County & & & & & & & $\mathrm{Y}$ & \\
\hline Employer $\times$ County & & & & & & & & Y \\
\hline$R^{2}$ & 0.001 & 0.067 & 0.067 & 0.068 & 0.080 & 0.067 & 0.068 & 0.189 \\
\hline
\end{tabular}

Notes: This table presents regression coefficients of annual changes in price-constant household portfolio equity shares on the zip code Republican contribution share, before and after the election, for various sets of controls. The price-constant equity share is calculated for a hypothetical portfolio that is insensitive to passive appreciations and is driven by trading only. The baseline controls are the lagged equity share, age, gender, marital status, log lagged financial wealth, log labor income in 2015, the lagged winning and losing sectors shares of equity, and zip code house price growth (2010-2015), interacted by annual indicators. In specifications (3)-(8) we consider additional sets of controls (interacted by yearly dummies) that include ex post income growth (2016-2017) and house price growth (2015-2017), employer industry indicators (3-digit NAICS), employer indicators, state indicators, county indicators, and employer $\times$ county indicators. The sample is our full set of RI households between October 2015 and October 2017, for which we observe the complete set of controls ( $27.7 \%$ of all RIs). Standard errors are clustered at the zip code level. 
Table 4: Regressions of Price-Constant Equity Share Changes on Likely Political Affiliation for Active Investors

\begin{tabular}{|c|c|c|c|c|c|c|c|c|}
\hline & \multicolumn{8}{|c|}{ One-year difference in price-constant equity share (in \%), active households } \\
\hline & (1) & (2) & (3) & (4) & (5) & (6) & (7) & (8) \\
\hline Zip code Republican contribution share & $\begin{array}{l}-0.172 \\
(0.220)\end{array}$ & $\begin{array}{l}-0.581 \\
(0.218)\end{array}$ & $\begin{array}{l}-0.559 \\
(0.218)\end{array}$ & $\begin{array}{l}-0.148 \\
(0.212)\end{array}$ & $\begin{array}{l}-0.216 \\
(0.228)\end{array}$ & $\begin{array}{l}-0.570 \\
(0.251)\end{array}$ & $\begin{array}{l}-0.983 \\
(0.324)\end{array}$ & $\begin{array}{l}-0.533 \\
(0.443)\end{array}$ \\
\hline Zip code Republican contribution share $\times$ Post & $\begin{array}{c}3.574 \\
(0.358)\end{array}$ & $\begin{array}{c}3.113 \\
(0.314)\end{array}$ & $\begin{array}{c}3.139 \\
(0.315)\end{array}$ & $\begin{array}{c}2.447 \\
(0.310)\end{array}$ & $\begin{array}{c}2.292 \\
(0.335)\end{array}$ & $\begin{array}{c}2.824 \\
(0.358)\end{array}$ & $\begin{array}{c}2.751 \\
(0.472)\end{array}$ & $\begin{array}{c}1.850 \\
(0.638)\end{array}$ \\
\hline Lagged equity share & & $\begin{array}{l}-25.543 \\
(0.205)\end{array}$ & $\begin{array}{l}-25.541 \\
(0.205)\end{array}$ & $\begin{array}{l}-25.765 \\
(0.206)\end{array}$ & $\begin{array}{c}-26.292 \\
(0.214)\end{array}$ & $\begin{array}{l}-25.548 \\
(0.205)\end{array}$ & $\begin{array}{c}-25.666 \\
(0.206)\end{array}$ & $\begin{array}{l}-26.807 \\
(0.280)\end{array}$ \\
\hline Lagged equity share $\times$ Post & & $\begin{array}{l}-5.078 \\
(0.272)\end{array}$ & $\begin{array}{l}-5.081 \\
(0.272)\end{array}$ & $\begin{array}{l}-4.893 \\
(0.273)\end{array}$ & $\begin{array}{l}-4.631 \\
(0.284)\end{array}$ & $\begin{array}{l}-5.074 \\
(0.272)\end{array}$ & $\begin{array}{l}-4.981 \\
(0.274)\end{array}$ & $\begin{array}{l}-4.246 \\
(0.373)\end{array}$ \\
\hline Age & & $\begin{array}{l}-0.225 \\
(0.005)\end{array}$ & $\begin{array}{l}-0.224 \\
(0.005)\end{array}$ & $\begin{array}{l}-0.226 \\
(0.005)\end{array}$ & $\begin{array}{l}-0.226 \\
(0.005)\end{array}$ & $\begin{array}{l}-0.224 \\
(0.005)\end{array}$ & $\begin{array}{l}-0.225 \\
(0.005)\end{array}$ & $\begin{array}{l}-0.228 \\
(0.007)\end{array}$ \\
\hline Age $\times$ Post & & $\begin{array}{c}0.012 \\
(0.007)\end{array}$ & $\begin{array}{c}0.012 \\
(0.007)\end{array}$ & $\begin{array}{c}0.010 \\
(0.007)\end{array}$ & $\begin{array}{c}0.007 \\
(0.007)\end{array}$ & $\begin{array}{c}0.010 \\
(0.007)\end{array}$ & $\begin{array}{c}0.010 \\
(0.007)\end{array}$ & $\begin{array}{c}0.001 \\
(0.010)\end{array}$ \\
\hline Female & & $\begin{array}{l}1.337 \\
(0.075)\end{array}$ & $\begin{array}{c}1.343 \\
(0.075)\end{array}$ & $\begin{array}{c}0.969 \\
(0.078)\end{array}$ & $\begin{array}{c}0.851 \\
(0.081)\end{array}$ & $\begin{array}{c}1.264 \\
(0.075)\end{array}$ & $\begin{array}{c}1.231 \\
(0.076)\end{array}$ & $\begin{array}{c}0.836 \\
(0.110)\end{array}$ \\
\hline Female $\times$ Post & & $\begin{array}{l}-1.966 \\
(0.109)\end{array}$ & $\begin{array}{l}-1.963 \\
(0.109)\end{array}$ & $\begin{array}{l}-1.547 \\
(0.113)\end{array}$ & $\begin{array}{l}-1.398 \\
(0.119)\end{array}$ & $\begin{array}{l}-1.869 \\
(0.108)\end{array}$ & $\begin{array}{l}-1.813 \\
(0.110)\end{array}$ & $\begin{array}{l}-1.220 \\
(0.160)\end{array}$ \\
\hline Married & & $\begin{array}{l}-0.008 \\
(0.085)\end{array}$ & $\begin{array}{l}-0.006 \\
(0.085)\end{array}$ & $\begin{array}{l}-0.012 \\
(0.085)\end{array}$ & $\begin{array}{c}0.002 \\
(0.090)\end{array}$ & $\begin{array}{c}0.030 \\
(0.085)\end{array}$ & $\begin{array}{c}0.026 \\
(0.085)\end{array}$ & $\begin{array}{c}0.005 \\
(0.122)\end{array}$ \\
\hline Married $\times$ Post & & $\begin{array}{c}0.386 \\
(0.125)\end{array}$ & $\begin{array}{c}0.387 \\
(0.125)\end{array}$ & $\begin{array}{c}0.348 \\
(0.125)\end{array}$ & $\begin{array}{c}0.228 \\
(0.132)\end{array}$ & $\begin{array}{c}0.318 \\
(0.125)\end{array}$ & $\begin{array}{c}0.303 \\
(0.127)\end{array}$ & $\begin{array}{c}0.296 \\
(0.177)\end{array}$ \\
\hline Log wealth & & $\begin{array}{l}-0.639 \\
(0.039)\end{array}$ & $\begin{array}{l}-0.639 \\
(0.039)\end{array}$ & $\begin{array}{l}-0.584 \\
(0.039)\end{array}$ & $\begin{array}{c}-0.573 \\
(0.041)\end{array}$ & $\begin{array}{l}-0.620 \\
(0.039)\end{array}$ & $\begin{array}{c}-0.608 \\
(0.039)\end{array}$ & $\begin{array}{l}-0.588 \\
(0.057)\end{array}$ \\
\hline Log wealth $\times$ Post & & $\begin{array}{c}0.253 \\
(0.059)\end{array}$ & $\begin{array}{c}0.256 \\
(0.059)\end{array}$ & $\begin{array}{c}0.178 \\
(0.058)\end{array}$ & $\begin{array}{c}0.091 \\
(0.062)\end{array}$ & $\begin{array}{c}0.229 \\
(0.058)\end{array}$ & $\begin{array}{c}0.205 \\
(0.058)\end{array}$ & $\begin{array}{c}0.161 \\
(0.084)\end{array}$ \\
\hline Log labor income 2015 & & $\begin{array}{c}0.332 \\
(0.070)\end{array}$ & $\begin{array}{c}0.343 \\
(0.071)\end{array}$ & $\begin{array}{c}0.311 \\
(0.072)\end{array}$ & $\begin{array}{c}0.397 \\
(0.079)\end{array}$ & $\begin{array}{c}0.306 \\
(0.071)\end{array}$ & $\begin{array}{c}0.336 \\
(0.072)\end{array}$ & $\begin{array}{c}0.397 \\
(0.110)\end{array}$ \\
\hline Log labor income $2015 \times$ Post & & $\begin{array}{l}-0.077 \\
(0.103)\end{array}$ & $\begin{array}{l}-0.067 \\
(0.104)\end{array}$ & $\begin{array}{c}0.020 \\
(0.105)\end{array}$ & $\begin{array}{c}0.059 \\
(0.117)\end{array}$ & $\begin{array}{l}-0.025 \\
(0.104)\end{array}$ & $\begin{array}{l}-0.019 \\
(0.106)\end{array}$ & $\begin{array}{c}0.016 \\
(0.162)\end{array}$ \\
\hline Controls by year & & & & & & & & \\
\hline $\begin{array}{l}\text { Baseline } \\
\text { Labor income growth 2016-17 } \\
\text { Zip code house price growth 2015-17 }\end{array}$ & & Y & $\begin{array}{l}\mathrm{Y} \\
\mathrm{Y} \\
\mathrm{Y}\end{array}$ & Y & $\mathrm{Y}$ & Y & Y & Y \\
\hline Employer industry & & & & Y & & & & \\
\hline Employer & & & & & Y & & & \\
\hline State & & & & & & Y & & \\
\hline $\begin{array}{l}\text { County } \\
\text { Employer } \times \text { County }\end{array}$ & & & & & & & Y & Y \\
\hline$R^{2}$ & 0.011 & 0.156 & 0.157 & 0.160 & 0.207 & 0.158 & 0.165 & 0.417 \\
\hline
\end{tabular}

Notes: This table presents regression coefficients of annual changes in price-constant household portfolio equity shares on the zip code Republican contribution share, before and after the election, for various sets of controls. The price-constant equity share is calculated for a hypothetical portfolio that is insensitive to passive appreciations and is driven by trading only. The baseline controls are the lagged equity share, age, gender, marital status, log lagged financial wealth, log labor income in 2015, the lagged winning and losing sectors shares of equity, and zip code house price growth (2010-2015), interacted by annual indicators. In specifications (3)-(8) we consider additional sets of controls (interacted by yearly dummies) that include ex post income growth (2016-2017) and house price growth (2015-2017), employer industry indicators (3-digit NAICS), employer indicators, state indicators, county indicators, and employer $\times$ county indicators. The sample is the subset of households with an active portfolio reallocation in the prior year $(11.1 \%$ of RIs). The sample period is October 2015 to October 2017, and we include RIs for which we observe the complete set of controls (23.6\% of active RIs). Standard errors are clustered at the zip code level. 


\section{Table 5: Regressions of Price-Constant Equity Share Changes on Likely Political Affiliation, Het- erogeneous Treatment Effects}

\begin{tabular}{|c|c|c|c|c|c|c|}
\hline & \multicolumn{6}{|c|}{$\begin{array}{l}\text { One-year difference in price-constant equity } \\
\text { share (in \%), all households }\end{array}$} \\
\hline & (1) & (2) & (3) & (4) & (5) & (6) \\
\hline Zip code Republican contribution share & $\begin{array}{l}-0.160 \\
(0.059)\end{array}$ & $\begin{array}{l}-0.133 \\
(0.057)\end{array}$ & $\begin{array}{l}-0.167 \\
(0.059)\end{array}$ & $\begin{array}{l}-0.204 \\
(0.060)\end{array}$ & $\begin{array}{l}-0.162 \\
(0.059)\end{array}$ & $\begin{array}{l}-0.187 \\
(0.060)\end{array}$ \\
\hline $\begin{array}{l}\text { Zip code Republican contribution share } \\
\times \text { Post }\end{array}$ & $\begin{array}{c}0.859 \\
(0.091)\end{array}$ & $\begin{array}{c}0.620 \\
(0.088)\end{array}$ & $\begin{array}{c}0.868 \\
(0.091)\end{array}$ & $\begin{array}{c}0.910 \\
(0.091)\end{array}$ & $\begin{array}{l}0.858 \\
(0.091)\end{array}$ & $\begin{array}{c}0.879 \\
(0.091)\end{array}$ \\
\hline $\begin{array}{l}\text { Active before } \\
\times \text { Zip code Republican contribution share } \\
\text { Active before } \times \text { Post } \\
\quad \times \text { Zip code Republican contribution share }\end{array}$ & & $\begin{array}{c}-0.222 \\
(0.226) \\
2.535 \\
(0.359)\end{array}$ & & & & \\
\hline$\stackrel{\text { Age }}{\times \text { Zip code Republican contribution share }}$ & & & $\begin{array}{l}-0.045 \\
(0.004)\end{array}$ & & & $\begin{array}{l}-0.036 \\
(0.005)\end{array}$ \\
\hline $\begin{array}{l}\text { Age } \times \text { Post } \\
\quad \times \text { Zip code Republican contribution share }\end{array}$ & & & $\begin{array}{c}0.051 \\
(0.005)\end{array}$ & & & $\begin{array}{c}0.003 \\
(0.007)\end{array}$ \\
\hline $\begin{array}{l}\text { Log wealth } \\
\quad \times \text { Zip code Republican contribution share }\end{array}$ & & & & $\begin{array}{l}-0.238 \\
(0.035)\end{array}$ & & $\begin{array}{l}-0.074 \\
(0.038)\end{array}$ \\
\hline $\begin{array}{l}\text { Log wealth } \times \text { Post } \\
\quad \times \text { Zip code Republican contribution share }\end{array}$ & & & & $\begin{array}{c}0.355 \\
(0.056)\end{array}$ & & $\begin{array}{c}0.254 \\
(0.063)\end{array}$ \\
\hline $\begin{array}{l}\text { Log income } \\
\times \text { Zip code Republican contribution share }\end{array}$ & & & & $\begin{array}{l}-0.216 \\
(0.082)\end{array}$ & & $\begin{array}{l}-0.273 \\
(0.082)\end{array}$ \\
\hline $\begin{array}{l}\text { Log income } \times \text { Post } \\
\quad \times \text { Zip code Republican contribution share }\end{array}$ & & & & $\begin{array}{c}0.626 \\
(0.130)\end{array}$ & & $\begin{array}{c}0.707 \\
(0.131)\end{array}$ \\
\hline $\begin{array}{l}\text { Lagged equity share } \\
\quad \times \text { Zip code Republican contribution share }\end{array}$ & & & & & $\begin{array}{c}0.590 \\
(0.316)\end{array}$ & $\begin{array}{l}-0.001 \\
(0.350)\end{array}$ \\
\hline $\begin{array}{l}\text { Lagged equity share } \times \text { Post } \\
\quad \times \text { Zip code Republican contribution share }\end{array}$ & & & & & $\begin{array}{l}-3.261 \\
(0.389)\end{array}$ & $\begin{array}{l}-3.001 \\
(0.437)\end{array}$ \\
\hline \multicolumn{7}{|l|}{ Controls by year } \\
\hline Baseline & Y & Y & Y & Y & Y & Y \\
\hline Employer $\times$ County & $\mathrm{Y}$ & $\mathrm{Y}$ & Y & Y & Y & $\mathrm{Y}$ \\
\hline$R^{2}$ & 0.189 & 0.191 & 0.189 & 0.189 & 0.189 & 0.189 \\
\hline
\end{tabular}

Notes: This table presents regression coefficients of annual changes in price-constant household portfolio equity shares on the zip code Republican contribution share, before and after the election. To estimate heterogeneous treatment effects, we also interact the zip code Republican contribution share each year by a dummy for active portfolio reallocation in the preceding year, age (demeaned), log initial wealth (demeaned), log labor income in 2015 (demeaned), and the initial equity share (demeaned). The price-constant equity share is calculated for a hypothetical portfolio that is insensitive to passive appreciations and is driven by trading only. The baseline controls are the lagged equity share, age, gender, marital status, log lagged financial wealth, log labor income in 2015, the lagged winning and losing sectors shares of equity, and zip code house price growth (20102015), interacted by annual indicators. In addition, we control for employer $\times$ county $\times$ period fixed effects. The sample is our full set of RI households between October 2015 and October 2017, for which we observe the complete set of controls ( $27.7 \%$ of all RIs). Standard errors are clustered at the zip code level. 
Table 6: Regressions of Price-Constant Equity Share Changes on Likely Political Affiliation for Subsamples

\begin{tabular}{|c|c|c|c|c|c|c|c|c|}
\hline & \multicolumn{8}{|c|}{ One-year difference in price-constant equity share (in \%) } \\
\hline & All & $\begin{array}{l}\text { Advised } \\
\text { account }\end{array}$ & Single & $\begin{array}{c}\text { Ret. } \\
\text { wealth }\end{array}$ & $\begin{array}{l}\text { Non-ret. } \\
\text { owner }\end{array}$ & $\begin{array}{l}\text { Only } \\
\text { ret. } \\
\text { owner }\end{array}$ & $\begin{array}{l}\text { Non-ret. } \\
\text { wealth }\end{array}$ & $\begin{array}{c}\text { Ret. } \\
\text { wealth, } \\
\text { non-ret. } \\
\text { owner }\end{array}$ \\
\hline & (1) & $(2)$ & (3) & (4) & (5) & (6) & (7) & (8) \\
\hline Zip code Republican contribution share & $\begin{array}{l}-0.160 \\
(0.059)\end{array}$ & $\begin{array}{l}-0.618 \\
(0.677)\end{array}$ & $\begin{array}{l}-0.245 \\
(0.103)\end{array}$ & $\begin{array}{l}-0.168 \\
(0.058)\end{array}$ & $\begin{array}{l}-0.325 \\
(0.213)\end{array}$ & $\begin{array}{l}-0.138 \\
(0.061)\end{array}$ & $\begin{array}{c}0.134 \\
(0.343)\end{array}$ & $\begin{array}{l}-0.428 \\
(0.215)\end{array}$ \\
\hline Zip code Republican contribution share $\times$ Post & $\begin{array}{c}0.859 \\
(0.091)\end{array}$ & $\begin{array}{c}0.923 \\
(1.050)\end{array}$ & $\begin{array}{c}0.670 \\
(0.162)\end{array}$ & $\begin{array}{c}0.835 \\
(0.090)\end{array}$ & $\begin{array}{c}1.252 \\
(0.328)\end{array}$ & $\begin{array}{c}0.796 \\
(0.094)\end{array}$ & $\begin{array}{c}0.198 \\
(0.490)\end{array}$ & $\begin{array}{c}1.283 \\
(0.326)\end{array}$ \\
\hline \multicolumn{9}{|l|}{ Controls by year } \\
\hline Baseline & $\mathrm{Y}$ & $\mathrm{Y}$ & Y & Y & Y & Y & Y & Y \\
\hline Employer $\times$ County & $\mathrm{Y}$ & $\mathrm{Y}$ & Y & $\mathrm{Y}$ & Y & Y & Y & Y \\
\hline$R^{2}$ & 0.189 & 0.570 & 0.257 & 0.188 & 0.307 & 0.197 & 0.312 & 0.304 \\
\hline Share of observations & $100.0 \%$ & $1.5 \%$ & $28.2 \%$ & $100.0 \%$ & $12.6 \%$ & $87.4 \%$ & $12.7 \%$ & $12.6 \%$ \\
\hline
\end{tabular}

Notes: This table presents regression coefficients of annual changes in price-constant household portfolio equity shares on the zip code Republican contribution share, before and after the election, in various subsamples of the population: households with advised accounts (column 2), households with a single (not married) head of household (column 3), wealth in retirement accounts only (4), households with a non-retirement account (column 5), households with only retirement accounts (column 6), wealth in non-retirement accounts only (column 7), and wealth in retirement accounts for households with a non-retirement account (column 8). The price-constant equity share is calculated for a hypothetical portfolio that is insensitive to passive appreciations and is driven by trading only. The baseline controls are the lagged equity share, age, gender, marital status, log lagged financial wealth, log labor income in 2015, the lagged winning and losing sectors shares of equity, and zip code house price growth (2010-2015), interacted by annual indicators. In addition, we control for employer $\times$ county $\times$ period fixed effects. The sample period is October 2015 to October 2017, and we include RIs for which we observe the complete set of controls ( $27.7 \%$ of all RIs in the full sample). Standard errors are clustered at the zip code level. 
Table 7: Regressions of Changes in Saving Rates on Likely Political Affiliation

\begin{tabular}{|c|c|c|c|c|c|c|c|c|}
\hline & \multicolumn{2}{|c|}{$\begin{array}{l}\text { Change in } \\
\text { net flow } \\
\text { rate }(\%)\end{array}$} & \multicolumn{2}{|c|}{$\begin{array}{l}\text { Change in net } \\
\text { saving rate }(\%), \\
\text { household }\end{array}$} & \multicolumn{2}{|c|}{$\begin{array}{l}\text { Change in net } \\
\text { saving rate }(\%), \\
\text { individual }\end{array}$} & \multicolumn{2}{|c|}{$\begin{array}{l}\text { Change in } \\
\text { contribution } \\
\text { rate }(\%)\end{array}$} \\
\hline & (1) & $(2)$ & (3) & $(4)$ & (5) & (6) & (7) & (8) \\
\hline Zip code Republican contribution share & $\begin{array}{l}-1.847 \\
(0.196)\end{array}$ & $\begin{array}{l}-0.417 \\
(0.239)\end{array}$ & $\begin{array}{l}-0.869 \\
(0.101)\end{array}$ & $\begin{array}{c}0.041 \\
(0.143)\end{array}$ & $\begin{array}{c}-0.732 \\
(0.121)\end{array}$ & $\begin{array}{l}0.073 \\
(0.171)\end{array}$ & $\begin{array}{l}-0.379 \\
(0.018)\end{array}$ & $\begin{array}{l}-0.118 \\
(0.026)\end{array}$ \\
\hline Zip code Republican contribution share $\times$ Post & $\begin{array}{c}1.682 \\
(0.192)\end{array}$ & $\begin{array}{c}0.833 \\
(0.254)\end{array}$ & $\begin{array}{c}0.700 \\
(0.159)\end{array}$ & $\begin{array}{c}0.751 \\
(0.277)\end{array}$ & $\begin{array}{c}0.597 \\
(0.213)\end{array}$ & $\begin{array}{c}0.635 \\
(0.308)\end{array}$ & $\begin{array}{l}-0.012 \\
(0.022)\end{array}$ & $\begin{array}{r}0.061 \\
(0.037)\end{array}$ \\
\hline $\begin{array}{l}\text { Controls by year } \\
\text { Baseline } \\
\text { Employer } \times \text { County }\end{array}$ & Y & $\begin{array}{l}\mathrm{Y} \\
\mathrm{Y}\end{array}$ & Y & $\begin{array}{l}\mathrm{Y} \\
\mathrm{Y}\end{array}$ & Y & $\begin{array}{l}\mathrm{Y} \\
\mathrm{Y}\end{array}$ & Y & $\begin{array}{l}\mathrm{Y} \\
\mathrm{Y}\end{array}$ \\
\hline $\begin{array}{l}R^{2} \\
\text { Share of observations }\end{array}$ & $\begin{array}{c}0.643 \\
100.0 \%\end{array}$ & $\begin{array}{c}0.706 \\
100.0 \%\end{array}$ & $\begin{array}{l}0.267 \\
96.6 \%\end{array}$ & $\begin{array}{l}0.360 \\
96.6 \%\end{array}$ & $\begin{array}{c}0.263 \\
96.6 \%\end{array}$ & $\begin{array}{r}0.375 \\
96.6 \%\end{array}$ & $\begin{array}{r}0.065 \\
87.8 \%\end{array}$ & $\begin{array}{r}0.188 \\
87.8 \%\end{array}$ \\
\hline
\end{tabular}

Notes: This table presents regression coefficients of annual changes in household saving measures on the zip code Republican contribution share, before and after the election. The net flow rate is constructed as yearly deposits minus withdrawals as a fraction of initial balances. The net saving rate is defined as yearly deposits minus withdrawals as a fraction of income (derived from dividing annual income evenly over the year). The contribution rate applies only to households actively contributing to a retirement account. The baseline controls are the lagged saving rate measure, lagged equity share, age, gender, marital status, log lagged financial wealth, log labor income in 2015, the lagged winning and losing sectors shares of equity, and zip code house price growth (2010-2015), interacted by annual indicators. In addition, we control for employer $\times$ county $\times$ period fixed effects in even columns. In column (7)-(8), we also control for the personalized default annual increases of contribution rates. The sample is our full set of RI households between October 2015 and October 2017, for which we observe the complete set of controls (27.7\% of all RIs). Standard errors are clustered at the zip code level. 
Table 8: Regressions of Changes in Portfolio Measures on Likely Political Affiliation

\begin{tabular}{|c|c|c|c|c|c|c|}
\hline \multirow{3}{*}{$\begin{array}{l}\text { A. Market betas } \\
\text { (one-year difference in price-constant beta, } \times 100 \text { ) }\end{array}$} & \multicolumn{3}{|c|}{ Beta of portfolio } & \multicolumn{3}{|c|}{ Beta of equity } \\
\hline & All & Active & Active & All & Active & Active \\
\hline & $(1)$ & (2) & (3) & (4) & (5) & (6) \\
\hline Zip code Republican contribution share & $\begin{array}{c}-0.120 \\
(0.068)\end{array}$ & $\begin{array}{c}-0.263 \\
(0.550)\end{array}$ & $\begin{array}{c}0.235 \\
(0.265)\end{array}$ & $\begin{array}{l}-0.007 \\
(0.051)\end{array}$ & $\begin{array}{c}0.226 \\
(0.512)\end{array}$ & $\begin{array}{c}0.778 \\
(0.247)\end{array}$ \\
\hline Zip code Republican contribution share $\times$ Post & $\begin{array}{c}0.831 \\
(0.113)\end{array}$ & $\begin{array}{c}1.416 \\
(0.845)\end{array}$ & $\begin{array}{c}2.011 \\
(0.398)\end{array}$ & $\begin{array}{c}-0.014 \\
(0.082)\end{array}$ & $\begin{array}{l}-1.151 \\
(0.765)\end{array}$ & $\begin{array}{c}-0.624 \\
(0.358)\end{array}$ \\
\hline \multicolumn{7}{|l|}{ Controls by year } \\
\hline Baseline & $\mathrm{Y}$ & $\mathrm{Y}$ & Y & Y & $\mathrm{Y}$ & Y \\
\hline Employer $\times$ County & $\mathrm{Y}$ & $\mathrm{Y}$ & & $\mathrm{Y}$ & Y & \\
\hline$R^{2}$ & 0.175 & 0.392 & 0.119 & 0.174 & 0.358 & 0.104 \\
\hline \multirow[t]{3}{*}{$\begin{array}{l}\text { B. Sector and global allocations } \\
\text { (one-year difference in price-constant measures, in \%) }\end{array}$} & \multicolumn{2}{|c|}{$\begin{array}{l}\text { Winning sectors } \\
\text { share of equity }\end{array}$} & \multicolumn{2}{|c|}{$\begin{array}{l}\text { Losing sectors } \\
\text { share of equity }\end{array}$} & \multicolumn{2}{|c|}{$\begin{array}{l}\text { International } \\
\text { share of equity }\end{array}$} \\
\hline & All & $\overline{\text { Active }}$ & All & $\overline{\text { Active }}$ & All & Active \\
\hline & (7) & (8) & (9) & (10) & (11) & (12) \\
\hline Zip code Republican contribution share & $\begin{array}{c}0.017 \\
(0.032)\end{array}$ & $\begin{array}{c}0.053 \\
(0.257)\end{array}$ & $\begin{array}{c}0.004 \\
(0.025)\end{array}$ & $\begin{array}{c}0.052 \\
(0.215)\end{array}$ & $\begin{array}{c}-0.068 \\
(0.030)\end{array}$ & $\begin{array}{l}-0.497 \\
(0.217)\end{array}$ \\
\hline Zip code Republican contribution share $\times$ Post & $\begin{array}{l}-0.067 \\
(0.048)\end{array}$ & $\begin{array}{l}-0.359 \\
(0.367)\end{array}$ & $\begin{array}{l}-0.041 \\
(0.038)\end{array}$ & $\begin{array}{l}-0.588 \\
(0.327)\end{array}$ & $\begin{array}{l}-0.014 \\
(0.047)\end{array}$ & $\begin{array}{c}0.503 \\
(0.343)\end{array}$ \\
\hline \multicolumn{7}{|l|}{ Controls by year } \\
\hline Baseline & $\mathrm{Y}$ & $\mathrm{Y}$ & $\mathrm{Y}$ & $\mathrm{Y}$ & $\mathrm{Y}$ & Y \\
\hline Employer $\times$ County & $\mathrm{Y}$ & $\mathrm{Y}$ & $\mathrm{Y}$ & $\mathrm{Y}$ & Y & Y \\
\hline$R^{2}$ & 0.149 & 0.343 & 0.209 & 0.392 & 0.152 & 0.348 \\
\hline
\end{tabular}

Notes: This table presents regression coefficients of annual changes in price-constant household portfolio measures on the zip code Republican contribution share, before and after the election, for the full sample and for the subsample of households with an active portfolio reallocation in the prior year. The price-constant portfolio measures are calculated for a hypothetical portfolio that is insensitive to passive appreciations and is driven by trading only. Market betas are obtained by regressing monthly fund or security excess returns on the value-weighted CRSP market excess return over the period 2006-2019 with at least 24 observations. Winning (losing) sectors are sectors that did relatively well (poorly) between the election and the end of 2016. International equity holdings consist of individual foreign company stocks and funds that invest in international equity. The outcome variables that describe the composition of equity (columns (4)-(12)) are conditional on having strictly positive equity holdings. The baseline controls are the lagged portfolio measure, age, gender, marital status, log lagged financial wealth, log labor income in 2015, the lagged winning and losing sectors shares of equity, and zip code house price growth (2010-2015), interacted by annual indicators. In addition, we control for employer $\times$ county $\times$ period fixed effects in most columns. The sample period is October 2015 to October 2017, and we include RIs for which we observe the complete set of controls (27.7\% of all RIs in the full sample), $97.3 \%$ of which have strictly positive equity shares. Standard errors are clustered at the zip code level. 